This item was submitted to Loughborough's Research Repository by the author.

Items in Figshare are protected by copyright, with all rights reserved, unless otherwise indicated.

\title{
Critical success factors of medical technology supply chains
}

PLEASE CITE THE PUBLISHED VERSION

https://doi.org/10.1080/09537287.2019.1572248

PUBLISHER

(C) Taylor \& Francis

VERSION

AM (Accepted Manuscript)

PUBLISHER STATEMENT

This is an Accepted Manuscript of an article published by Taylor \& Francis in Production Planning and Control on 18 March 2019, available online: http://www.tandfonline.com/10.1080/09537287.2019.1572248.

\section{LICENCE}

CC BY-NC-ND 4.0

\section{REPOSITORY RECORD}

Garcia-Villarreal, Enrique, Ran Bhamra, and Martin Schoenheit. 2019. "Critical Success Factors of Medical Technology Supply Chains”. figshare. https://hdl.handle.net/2134/36813. 


\title{
Critical Success Factors of Medical Technology Supply Chains
}

\author{
Dr Enrique García-Villarreal, \\ Dr Schönheit + P. Consulting GmbH, Köln, Germany.
}

Dr Ran Bhamra, (r.s.bhamra@lboro.ac.uk)

Wolfson School of Mechanical, Electrical \& Manufacturing Engineering, Loughborough University, UK.

Dr. Martin Schoenheit, Dr Schönheit + P. Consulting GmbH, Köln, Germany. 


\begin{abstract}
This paper investigates Critical Success Factors that affect the performance of organisations involved in Medical Technology supply chains (MTSCs) in Germany. The Medical Technology sector in Germany is considered an innovative, fast-growing and promising industry, being third behind the USA and China as the biggest market in the world, worth 29.9 billion euros in 2017. MTSCs in this country are under pressure from health service funding and cheaper imports, primarily from China. Consequently, supply chain success is of high importance and OEM operational improvements are critical. This exploratory study involved a multiple case study approach where 15 OEMs within German MTSCs were investigated. Following within-case and cross-case analysis, empirical results led to the development of testable propositions, which constitute a foundation for further research investigation. The findings show that there are six, prioritised Critical Success Factors for MTSCs that include sales and operations planning, product development process, and quality and compliance. These findings challenge existing assumptions about Critical Success Factors within MTSCs, providing practitioners with strategies showing that re-prioritised CSFs should improve operational performance of OEMs.
\end{abstract}

\title{
Keywords
}

Critical Success Factors, Supply Chain Management, Medical Technology, Case study. 


\section{Introduction}

Medical Technology is any technology applied to save the lives of people affected by a wide array of conditions (Medtech Europe, 2017) and ranges from mass production items such as sticking plasters, syringes or latex gloves, to specific equipment such as wheelchairs and hearing aids, to high-tech devices such as pacemakers, replacement joints for knees and hips, to intelligent contact lenses (Eucomed, 2015; Medtech Europe, 2017). Medical Technology is considered to be an innovative, fast-growing and promising industry, particularly so in Germany as it is the third largest market in the world behind the United States of America and China (BVMed, 2018). In addition to some large companies, around 1,200 small and mediumsized enterprises (SMEs) constitute the core of the sector (BMBF, 2017), with 93\% of the organisations providing work for less than 250 employees. In 2017, the total sales volume of Medical Technology organisations rose to 29.9 billion euros, with an export rate of $64 \%$ (BVMed, 2018).

Despite this impressive growth, the Medical Technology industry in Germany is faced with a number of challenges. Reportedly, Germany's statutory health insurance fund (gesetzliche Krankenversicherung) has experienced funding difficulties, forcing administrators to reduce fees and thus expenditures on Medical Technology (Hartford, 2014; Focus, 2016). Furthermore, manufacturers rely strongly on new product development to sustain or increase their market share, and with products having lifecycles not longer than 3 years, short development times and regulatory approvals become critical issues (Hempel, 2017; BVMed, 2018). Additionally, Chinese and Indian companies are also lined up to be frontrunners in terms of cost, workforce, and market capture, pressuring German manufacturers to produce and distribute cost-efficient devices (Marucheck et al, 2011; Hempel, 2017). In this environment, the search for rationalisation potential becomes critical. Studies (J \& M, 2010) show that a 
defined supply chain strategy often falls short in this sector. Major deficiencies reported are the absence of a formulated strategy, the lack of efficient planning and coordination processes, along with unreliable sales forecasts.

Understanding which key features lead to better performance of organisations within Medical Technology Supply Chains (MTSCs) is therefore imperative. In this paper, we investigate multiple cases of OEMs involved in MTSCs and use the results of the analysis to identify those Critical Success Factors (CSFs) that practitioners in the field prioritise in pursuing opportunities and areas of improvement which require addressing during the design and implementation of their Supply Chain Management (SCM) strategies. These findings are then fully discussed in the light of the extant literature.

This paper is organised as follows: Section 2 presents a review of the literature. Section 3 provides a detailed description of the methodology and case study design. Section 4 presents the findings, data analysis, and discussion within the context of literature on CSFs in SCM. Section 5 concludes the paper with implications for theory and management practice along with research limitations and avenues for further research.

\section{Literature review}

Supply chain management as an area in operations management literature is extremely well served (Kache \& Seuring, 2014; Sweeney et al, 2015) whereas there is a real dearth regarding its focus on Medical Technology supply chains and their agility as exemplified, over some time, by literature (Rivard-Royer et al, 2002; Bakker et al, 2008; Gligor, 2014; Mandal, 2017).

\subsection{Healthcare \& Medical Technology Supply Chains}

Mentzer et al (2001, p. 4) define supply chains as a "set of three or more entities directly involved in the upstream and downstream flow of products, services, finances, and information 
from a source to the customer". There are three major players in the Medical Technology supply chain: producers (product manufacturers), purchasers (group purchasing organisations, or GPOs, and wholesalers/distributors), and health care providers (hospital systems and integrated delivery networks, or IDNs) (Burns et al, 2002). The manufacturers (producers) in the supply chain can be broadly classified into three groups namely, pharmaceutical, medicalsurgical, and device manufacturers, the latter being the object of this study. Their products are then purchased by group purchasing organisations (GPO), wholesalers, distributors and in some cases independent contractors and delivered to providers like hospitals, IDNs, physicians (individual clinics) and pharmacies. Customers (payers) in this supply chain are local governments, employers, and individuals. They pay the providers through fiscal intermediaries like insurers, health maintenance organisations (HMOs) and pharmacy-benefit managers.

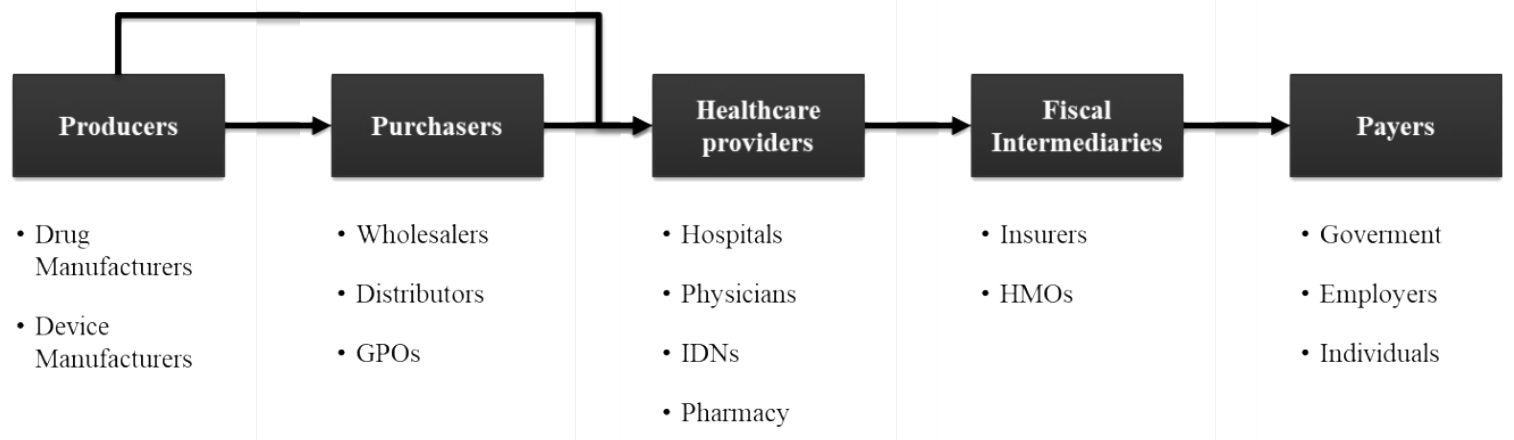

Figure 1: Healthcare value chain (Burns et al, 2002)

Smith et al (2012) provides a detailed view of the medical devices supply chain, in which the main product flows between the key players are clearly represented (see Figure 2), underlining the heavy influence of intermediaries or third-party players. 


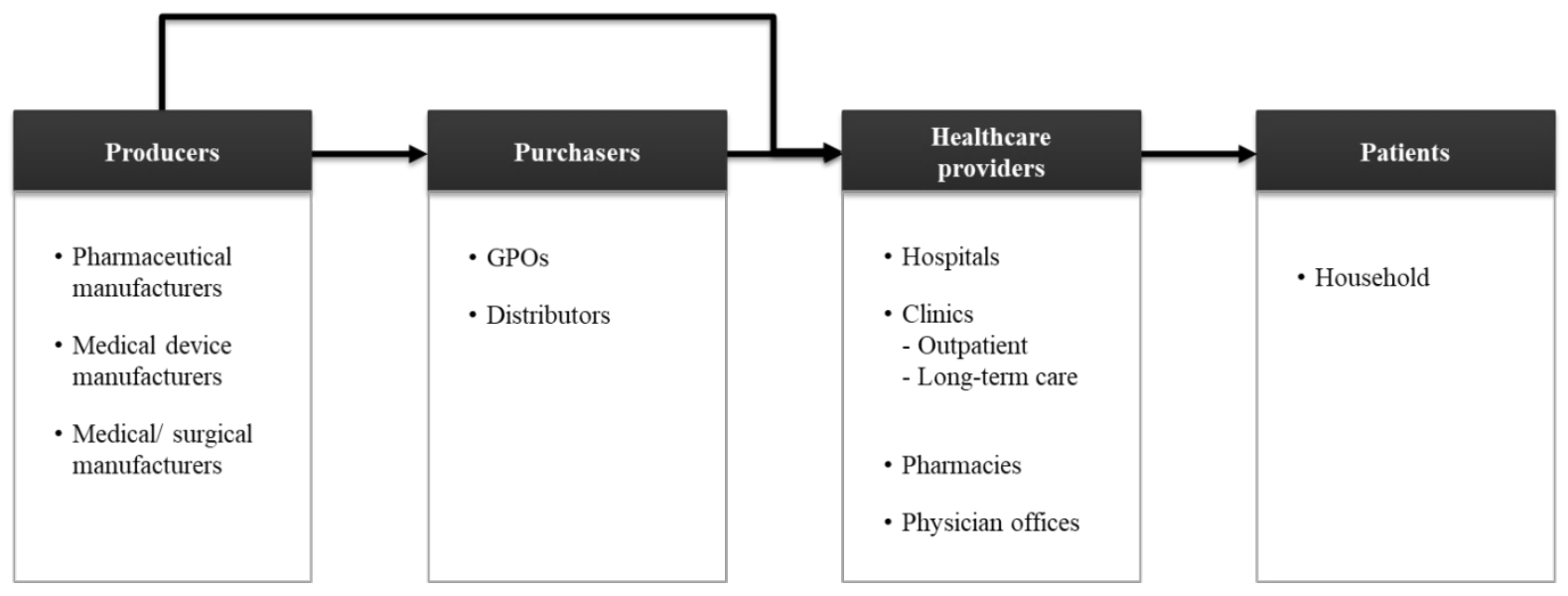

Figure 2: Detailed view of the medical devices supply chain (Smith et al, 2012, p. 3)

Some notable and recent studies have focused on reverse logistics issues in supply chains, (Xie et al, 2018; Panjehfouladgaran et al, 2018; Cole et al, 2018). Studies by Burns (2000), DacostaClaro (2002), J and M Research (2010), and Mayr (2013) indicate that a significant portion of the costs associated with supply chains in the health care sector can be reduced by adopting strategies already deployed by the industry sector. In order to provide guidelines for practitioners to adopt the necessary organisational changes, the identification of Critical Success Factors becomes very important (Ngai et al, 2004).

\subsection{Critical Success Factors (CSFs)}

There are certain key elements in business that, if working properly, can ensure successful competitive performance for an organisation (Rockart, 1979). Rockart (1979) called these key areas Critical Success Factors (CSFs) and defined them as "areas or activities that should receive constant and careful attention from management”. According to Alazmi and Zairi (2003), CSFs are "areas in which results ensure successful competitive advantage". CSFs are used, for example, to identify critical issues in planning implementation, to achieve better organisational performance, to assist managers to execute a better resource allocation, and to 
serve as guidelines to monitor an organisation's activities (Talib \& Hamid, 2014; Boynton \& Zmud, 1984). The concept of Critical Success Factors has been applied in several fields. Studies on CSFs can be found on Management Information Systems Planning (Munro \& Wheeler, 1980), Knowledge Management (Wong, 2005; Alazmi \& Zairi, 2003), New Product Design (Cheng \& Shiu, 2008; Cooper \& Kleinschmidt, 1995), Insurance Sales (Keck, Leigh, \& Lollar, 1995), ERP implementation initiatives (Hong \& Kim, 2002; Akkermans \& van Helden, 2002), Project Management (Belassi \& Tukel, 1996), Online Education (Volery \& Lord, 2000), Six Sigma Implementation Initiatives (Coronado \& Antony, 2002), Lean Implementation Initiatives (Achanga et al, 2006), Construction Projects (Sanvido et al, 1992), Business Process Management (Trkman, 2010), Total Quality Management (Antony et al, 2002), and Environmental Management (Zutshi \& Sohal, 2004), among many others.

\subsection{Critical Success Factors in Supply Chain Management}

Early applications of CSFs in logistics and SCM were first found in studies such as Cooper and Ellram (1993), Chiu (1995), Tate (1995), and Korpela and Tuominen (1996). In the field of SCM, Gunasekaran and Ngais' (2003) work on a small third-party logistics (3PL) company in Hong Kong, they designed a framework for developing an efficient 3PL system, with factors such as 'strategic planning', 'inventory management', 'transportation planning', 'capacity planning', and 'information management' as the major dimensions. Li et al (2006) investigated 196 organisations and used structural equation modelling to develop five dimensions of SCM practice: 'strategic supplier partnership', customer relationship', 'level of information sharing', 'quality of information sharing', and 'postponement'. Their work indicated that higher levels of SCM practice regarding these dimensions can lead to enhanced competitive advantage and thus provide organisations with improved organisational performance. Tummala et al (2006) discovered that resource allocation could be enhanced in areas such as information systems, 
goal-setting, training, personnel, and aligning SCM initiatives with current priorities and committed resources. Cullen and Taylor (2009) proposed five factors ('system quality', 'information quality', 'management and use', 'world wide web - assurance and empathy', and 'trust') that practitioners perceive as successful for E-commerce. Furthermore, Power et al's (2001) study of the CSFs that influence the agility of organisations in managing their SCs proposed several factors in an agile SCM: 'customer satisfaction', 'average process changeover time', 'productivity', 'delivery in full on time', 'relative technological competitiveness', 'ratio of annual sales to average total stock', 'competitive advantage through process technology', 'competitive advantage through ability to develop new products', and 'product innovation'. Hong et al's (2008) work on the factors influencing performance of reverse supply chains (RSC) suggests that the 'ease of use', the 'perceived usefulness', the 'service quality', the 'channel relationship', and the 'reverse supply chain cost' are the most important factors which influence the success of reverse supply chains.

$\mathrm{Hu}$ and Hsu (2010) employed a survey on the electronics industry in Taiwan and factor analysis to identify 20 critical factors for implementing green SCM, which were then clustered into four dimensions: 'supplier management', 'product recycling', organisation involvement', and 'life cycle management'. On a study on Green Supply Chain Management, Kim and Rhee, (2012) found that 'planning and implementation' as well as 'collaboration with partners' and 'integration of structure' were key to a better performance of the organisations' initiatives. Lin et al (2013) conducted a study in order to identify the critical enablers and pathways to higher performance in Supply Chain Management. They concluded that enterprises need to pay attention to two main pathways: a 'compliance approach' and a 'voluntary approach'. Training programs, ISO, and suppler quality audit programs are suggested to address the former. As for initiating a voluntary effort in organisations, the authors suggest that firms need to instil 
'motivation' into a supply chain quality system. Talib and Hamid (2014) conducted a literature survey and an analysis of 42 studies and proposed four major CSFs in SCM: 'collaborative partnership', 'information technology', 'top management support', and 'human resources'. Finally, Nguyen (2017) conducted a literature survey based on a sample of 42 CSFs studies in several logistics and SCM fields, identifying 'collaborative partnership', 'information technology', 'top management support', and 'human resource' as Critical Success Factors.

Table 1 presents a summary of CSFs in SCM as identified by previous researchers.

\begin{tabular}{|c|c|c|c|}
\hline $\begin{array}{c}\text { Author/ } \\
\text { year }\end{array}$ & Research field & $\begin{array}{c}\text { Research } \\
\text { method }\end{array}$ & Identified Critical Success Factors \\
\hline Chiu (1995) & $\begin{array}{l}\text { Integrated Logistics } \\
\text { Management System }\end{array}$ & $\begin{array}{l}\text { Survey/ } \\
\text { Interviews }\end{array}$ & $\begin{array}{l}\text { Good logistics system planning; well-designed } \\
\text { distribution system; prudent selection of allied } \\
\text { companies; close relationship with trading partners; } \\
\text { good logistics investment analysis; logistics } \\
\text { management barriers elimination; top management } \\
\text { support; continuous improvement in logistics }\end{array}$ \\
\hline Tate (1995) & Logistics Partnership & Interviews & $\begin{array}{l}\text { Operational/culture/value compatibility; understanding } \\
\text { business needs; effective communication; mutual } \\
\text { commitment; flexibility; fairness; trust }\end{array}$ \\
\hline $\begin{array}{l}\text { Power et al, } \\
(2001)\end{array}$ & Agile Supply Chain & Survey & $\begin{array}{l}\text { Participative management style; computer-based } \\
\text { technology; resource management; continuous } \\
\text { improvement enablers; supplier relation; Just-in-Time } \\
\text { (JIT) methodology; technology utilization }\end{array}$ \\
\hline $\begin{array}{l}\text { Gunasekaran } \\
\text { and Ngai } \\
(2003)\end{array}$ & $\begin{array}{l}\text { Small Logistics } \\
\text { Companies }\end{array}$ & Case study & $\begin{array}{l}\text { Strategic planning; inventory management; } \\
\text { transportation planning; capacity planning; } \\
\text { information management }\end{array}$ \\
\hline $\begin{array}{l}\text { Chen and } \\
\text { Paulraj } \\
(2004)\end{array}$ & $\begin{array}{l}\text { Supply Chain Theory } \\
\text { Advancement }\end{array}$ & $\begin{array}{l}\text { Literature } \\
\text { review }\end{array}$ & $\begin{array}{l}\text { Environment uncertainty; customer focus; top } \\
\text { management support; supply strategy; information } \\
\text { technology; supply network structure; managing buyer- } \\
\text { supplier relationship; logistics integration }\end{array}$ \\
\hline $\begin{array}{l}\text { Gunasekaran } \\
\text { and Ngai } \\
(2004)\end{array}$ & Virtual Supply Chain & Interviews & $\begin{array}{l}\text { Strategic alliance; web-based information system; } \\
\text { automation for business process and re-engineering; } \\
\text { supply chain visibility; performance management } \\
\text { system }\end{array}$ \\
\hline $\begin{array}{l}\text { Ngai et al, } \\
(2004)\end{array}$ & $\begin{array}{l}\text { Web-based Supply } \\
\text { Chain } \\
\text { Management }\end{array}$ & Survey & $\begin{array}{l}\text { Communication; top management commitment; } \\
\text { training and education; data security; reliability of } \\
\text { hardware and software }\end{array}$ \\
\hline Ogden (2006) & Supply Base Reduction & Case study & $\begin{array}{l}\text { Top management support; cross-functional teams; } \\
\text { standardize part numbers and descriptions; supplier } \\
\text { performance evaluation system; good communication } \\
\text { during projects; win-win relationship; good information } \\
\text { system; hiring right people }\end{array}$ \\
\hline
\end{tabular}




\begin{tabular}{|c|c|c|c|}
\hline $\begin{array}{c}\text { Author/ } \\
\text { year }\end{array}$ & Research field & $\begin{array}{c}\text { Research } \\
\text { method }\end{array}$ & Identified Critical Success Factors \\
\hline $\begin{array}{l}\text { Tummala et } \\
\text { al, (2006) }\end{array}$ & $\begin{array}{l}\text { Operational Issues in } \\
\text { Supply Chain } \\
\text { Management } \\
\text { Implementation }\end{array}$ & Survey & $\begin{array}{l}\text { Customer-supplier relationship; information and } \\
\text { communication technology (ICT); re-engineering } \\
\text { material flow; creating corporate culture; performance } \\
\text { measurement }\end{array}$ \\
\hline $\begin{array}{l}\text { Hong et al, } \\
(2008)\end{array}$ & $\begin{array}{l}\text { Reverse Supply Chain } \\
\text { (RSC) }\end{array}$ & Survey & $\begin{array}{l}\text { Costs; technology capacity; government policy; } \\
\text { organizational commitment; channel relationship; } \\
\text { service quality; ease of use; perceived usefulness; RSC } \\
\text { performance }\end{array}$ \\
\hline $\begin{array}{l}\text { Kuei et al, } \\
(2008)\end{array}$ & $\begin{array}{l}\text { Supply Chain Quality } \\
\text { Management }\end{array}$ & $\begin{array}{l}\text { Literature } \\
\text { review }\end{array}$ & $\begin{array}{l}\text { Customer focus; quality of IT system; supplier } \\
\text { relationship; externally focused processed integration; } \\
\text { supply chain quality leadership }\end{array}$ \\
\hline $\begin{array}{l}\text { Cullen and } \\
\text { Taylor (2009) }\end{array}$ & $\begin{array}{l}\text { E-commerce in Supply } \\
\text { Chain }\end{array}$ & Survey & $\begin{array}{l}\text { System quality; information quality; management and } \\
\text { use; world wide web-assurance and empathy; trust }\end{array}$ \\
\hline $\begin{array}{l}\text { Pettit and } \\
\text { Beresford } \\
(2009)\end{array}$ & $\begin{array}{l}\text { Humanitarian Supply } \\
\text { Chain }\end{array}$ & $\begin{array}{l}\text { Literature } \\
\text { review }\end{array}$ & $\begin{array}{l}\text { Strategic planning; resource management; transport } \\
\text { planning; capacity planning; information management; } \\
\text { technology utilization; human resource management; } \\
\text { continuous improvement; supplier relationship; supply } \\
\text { chain strategy }\end{array}$ \\
\hline $\begin{array}{l}\text { Wu and Hsu } \\
(2009)\end{array}$ & $\begin{array}{l}\text { Collaboration in } \\
\text { Integrated Circuit (IC) } \\
\text { Supply Chain }\end{array}$ & $\begin{array}{l}\text { Literature } \\
\text { review }\end{array}$ & $\begin{array}{l}\text { Authorization and security; CAD and EDA tools; } \\
\text { co-design of equipment and tools; communication } \\
\text { technology; database management; data format, } \\
\text { transformation and interface; design for manufacturing; } \\
\text { design optimisation and technique; information sharing } \\
\text { mechanism; IP reuse; knowledge-based system; } \\
\text { strategic alliance, community and coalition }\end{array}$ \\
\hline $\begin{array}{l}\text { Hu and Hsu } \\
(2010)\end{array}$ & $\begin{array}{l}\text { Green Supply Chain } \\
\text { (GSC) }\end{array}$ & Survey & $\begin{array}{l}\text { Supplier management; product recycling; organisational } \\
\text { involvement; life cycle management }\end{array}$ \\
\hline $\begin{array}{l}\text { Koh et al, } \\
(2011)\end{array}$ & $\begin{array}{l}\text { ERP II Implementation } \\
\text { in } \\
\text { Supply Chain }\end{array}$ & Interviews & $\begin{array}{l}\text { Operational efficiency; efficient legacy enterprise } \\
\text { system; common partner goals; similar partner priority; } \\
\text { collaboration partner support; partner trust; partner } \\
\text { culture similarity; relationship change management; } \\
\text { data standard consistency }\end{array}$ \\
\hline $\begin{array}{l}\text { Lao et al, } \\
\text { (2011) }\end{array}$ & 3PL Selection & Survey & $\begin{array}{l}\text { Quality improvement; cost reduction; service quality; } \\
\text { reputation; primary customer loyalty; complaint }\end{array}$ \\
\hline Dinter (2012) & $\begin{array}{l}\text { Information Logistics } \\
\text { Strategy }\end{array}$ & Survey & $\begin{array}{l}\text { Comprehensiveness; flexibility; top management } \\
\text { support; communication; IT strategy orientation; } \\
\text { business IT partnership; project collaboration }\end{array}$ \\
\hline $\begin{array}{l}\text { Kim and } \\
\text { Rhee (2012) }\end{array}$ & $\begin{array}{l}\text { Green Supply Chain } \\
\text { (GSC) }\end{array}$ & Survey & $\begin{array}{l}\text { Collaboration with partners; mutual trust; green } \\
\text { business understanding; planning and implementation; } \\
\text { standardising and integration; activation of supporting } \\
\text { for GSC; strategic use of IT }\end{array}$ \\
\hline $\begin{array}{l}\text { Mothilal et } \\
\text { al, (2012) }\end{array}$ & 3PL Performance & Survey & $\begin{array}{l}\text { Breadth of services; industry focus; relationship with } \\
\text { 3PLs; investment in information system; skilled } \\
\text { professionals; supply chain integration }\end{array}$ \\
\hline $\begin{array}{l}\text { Lin et al, } \\
(2013)\end{array}$ & $\begin{array}{l}\text { Supply Chain Quality } \\
\text { Management }\end{array}$ & Case study & $\begin{array}{l}\text { Supplier relationship; information technology; process } \\
\text { management; top management support; human resource } \\
\text { management; quality management; strategic planning; } \\
\text { knowledge management }\end{array}$ \\
\hline
\end{tabular}




\begin{tabular}{|c|c|c|c|}
\hline $\begin{array}{c}\text { Author/ } \\
\text { year }\end{array}$ & Research field & $\begin{array}{l}\text { Research } \\
\text { method }\end{array}$ & Identified Critical Success Factors \\
\hline $\begin{array}{l}\text { Thakkar et al, } \\
\text { (2013) }\end{array}$ & SCM in SME & Case study & $\begin{array}{l}\text { Effective partnership; improve communication; } \\
\text { logistics integration; supply chain business strategy; } \\
\text { buyer-supplier relationship; effective planning and } \\
\text { control; trust among supply chain partners; } \\
\text { availability of performance management tools }\end{array}$ \\
\hline $\begin{array}{l}\text { Talib and } \\
\text { Hamid } \\
(2014)\end{array}$ & $\begin{array}{l}\text { Supply Chain } \\
\text { Management CSF }\end{array}$ & $\begin{array}{l}\text { Literature } \\
\text { review }\end{array}$ & $\begin{array}{l}\text { Top management support; human resource; information } \\
\text { technology; collaborative partnership }\end{array}$ \\
\hline $\begin{array}{l}\text { Gopal and } \\
\text { Thakkar } \\
(2016)\end{array}$ & CSFs in sustainable SCs & $\begin{array}{l}\text { Structural } \\
\text { modelling }\end{array}$ & $\begin{array}{l}\text { Identification of } 25 \text { leading and lagging CSFs in } \\
\text { sustainability implementation in the Indian automobile } \\
\text { industry }\end{array}$ \\
\hline $\begin{array}{l}\text { Luthra et al, } \\
\text { (2017) }\end{array}$ & $\begin{array}{l}\text { Green Supply Chain } \\
\text { (GSC) }\end{array}$ & Case study & $\begin{array}{l}\text { Internal management initiatives; customer support; } \\
\text { regulation; supplier management; social commitment; } \\
\text { supply chain competitiveness }\end{array}$ \\
\hline $\begin{array}{l}\text { Luthra et al, } \\
\text { (2018) }\end{array}$ & CSFs in sustainability & $\begin{array}{l}\text { Structural } \\
\text { modelling }\end{array}$ & $\begin{array}{l}\text { Identification of } 16 \text { diverse CSFs including Internal } \\
\text { management initiatives; customer support; regulation; } \\
\text { supplier management; social commitment; supply chain } \\
\text { competitiveness }\end{array}$ \\
\hline $\begin{array}{l}\text { Lou et al, } \\
(2018)\end{array}$ & SC excellence factors & Delphi study & SCM knowledge, education and supply chain culture \\
\hline
\end{tabular}

Table 1: Critical Success Factors in SCM

\subsection{Critical Success Factors in the Medical Technology Industry}

Research on Critical Success Factors in the Medical Technology industry in recent years has been focused towards medical device development, as companies in this market face intense competition, higher degrees of customer sophistication, and where the cost of medical devices greatly influences healthcare systems (Medina et al, 2013). Medina et al (2012) distinguishes between internal and external factors influencing medical device development. Internal factors focus on the organisational context within which design is carried out. Lucke et al (2009) cites the level of experience of designers as a major internal factor, with Chatterji (2009) suggesting that companies started by former employees of established medical device industries perform significantly better than other new entrants as the former benefit from past experiences on 
subjects such as regulatory strategy and marketing. Another internal factor relates to the effectiveness of communication of development priorities (Brown et al, 2008), where a new product development process is proposed based on their findings. Similarly, Rochford and Rudelius (1997) and Millson and Wilemon (1998) conclude that the execution of a development process that encompasses preliminary market analyses, financial analyses, and customer involvement is critical for the commercial success of medical devices.

In contrast, external factors relate mostly to cost and profit, research and development (R\&D), clinical research, and insurance companies' reimbursement (Advanced Medical Technology Association, 2003; Medina et al, 2013). Intellectual property protections and overseas market opportunities are identified, among others, as external factors (Medina et al, 2013). Finally, the Food and Drug Administration (FDA), the regulatory agency of medical devices marketed in the Unites States, is suggested as the primary external factor influencing companies' development priorities (Advanced Medical Technology Association, 2003; Medina et al, 2013).

To date, there has been no specific study on CSFs related to MTSCs available in the SCM literature. This paper directly addresses this urgent need from both the academic and practitioner perspectives.

\section{Methodology}

An exploratory research design was deployed, with a multiple case study approach selected for the following reasons. Firstly, the literature review revealed limited insights concerning CSFs in MTSCs. In such an embryonic research field, a qualitative research based on case studies 
can provide better means to identify patterns and develop theory, especially if the relationships between the constructs are undefined (Edmondson \& McManus, 2007). Secondly, as researchers are able to interact with respondents, perspectives are better understood and relevant processes can be closely investigated (Boyer \& Swink, 2008). Thirdly, case studies encourage management involvement, which enables the researchers to generate managerially relevant knowledge. For these reasons, we followed established methodological guidelines for case study research (Gibbert et al, 2008; Eisenhardt, 1989; Voss et al, 2002). Fifteen in-depth case studies of manufacturing organisations were conducted to obtain a greater understanding of the main issues of German MTSCs. The nature of the case studies was exploratory in order to build theory that could later be tested using survey data (Ellram, 1996).

\subsection{Research Question}

This study was driven by the following research question:

What are the Critical Success Factors (CSFs) for Original Equipment Manufacturers (OEMs) in German Medical Technology Supply Chains (MTSCs)?

Robson (2011) suggests that studies focusing their efforts on answering 'what', 'how' and 'why' questions call for a flexible, qualitative research design strategy. Following Robson (2011), this research question has been formulated specifying the population of interest (the MTSCs of German OEMs) and suggesting the nature of the study: exploratory rather than explanatory, as the focus of the research is to identify key variables (the aforementioned CSFs). Yin's (2009) approach to qualitative research design was followed and key components and their application to the study are elucidated below. 


\section{Propositions}

Due to the exploratory character of the research question and the dearth of literature on the subject, no specific propositions regarding the CSFs were created before data collection. Eisenhardt (1989) supports the notion not to develop propositions in all types of exploratory research. This study therefore discusses and analyses the empirical results to develop testable propositions.

\section{Unit of Analysis}

The unit of analysis enables the establishment of construct validity and helps to select and gather the appropriate types of data and their sources (2009). The unit of analysis of this study has been defined as the OEMs within German MTSCs. It is beyond the scope of this research to examine the perspectives of other actors in the German MTSCs (e.g., hospitals, third party sellers).

\subsection{Data Collection Design}

The number of required cases suggested by several authorities differs; generally, the more cases utilised in a case study research, the higher the degree of certainty and therefore, external validity (Eisenhardt, 1989; Yin, 2009). Ellram (2012) considers that "six to ten cases should provide compelling evidence to support or reject an initial set of propositions" while Eisenhardt (1989) argues that "with no more than ten cases, it quickly becomes difficult to cope with the complexity and volume of the data".

Contact letters were sent to 25 organisations that appeared suitable for the study. 17 expressed their interest in participating in the study. An initial telephone interview was undertaken with all participants to ensure that they qualified for inclusion in the study. Due to scheduling 
conflicts, two organisations were not available for an interview. Consequently, 15 organisations were part of the study. Table 2 provides a summary of the participating organisations.

\begin{tabular}{|c|c|c|c|c|c|}
\hline Nr. & Company & $\begin{array}{c}\text { Classification } \\
\text { according to the } \\
\text { GMDN Agency (2012) }\end{array}$ & Position of respondent & $\begin{array}{c}\text { Company size } \\
\text { according to IfM } \\
(2017)^{2}\end{array}$ & $\begin{array}{l}\text { Number of } \\
\text { employees }\end{array}$ \\
\hline 1 & A & Laboratory equipment & $\begin{array}{l}\text { Vice President of Supply } \\
\text { Chain }\end{array}$ & $\begin{array}{l}\text { Small and Medium } \\
\text { Enterprise (SME) }\end{array}$ & 300 \\
\hline 2 & $\mathrm{~B}$ & $\begin{array}{l}\text { Electromechanical } \\
\text { medical technology }\end{array}$ & $\begin{array}{l}\text { Vice President Global } \\
\text { Logistics }\end{array}$ & $\begin{array}{l}\text { Large Enterprise } \\
\text { (LE) }\end{array}$ & 53000 \\
\hline 3 & $\mathrm{C}$ & $\begin{array}{l}\text { Electromechanical } \\
\text { medical technology }\end{array}$ & $\begin{array}{l}\text { Manager of Logistics } \\
\text { Planning }\end{array}$ & $\begin{array}{l}\text { Large Enterprise } \\
\text { (LE) }\end{array}$ & 12500 \\
\hline 4 & $\mathrm{D}$ & $\begin{array}{l}\text { Non-active implantable } \\
\text { technology }\end{array}$ & $\begin{array}{l}\text { Director of Supply Chain } \\
\text { Management }\end{array}$ & $\begin{array}{l}\text { Large Enterprise } \\
\text { (LE) }\end{array}$ & 3400 \\
\hline 5 & $\mathrm{E}$ & $\begin{array}{l}\text { Electromechanical } \\
\text { medical technology }\end{array}$ & Head of Supply Chain & $\begin{array}{l}\text { Large Enterprise } \\
\text { (LE) }\end{array}$ & 6000 \\
\hline 6 & $\mathrm{~F}$ & Reusable instruments & $\begin{array}{l}\text { Manager of Logistics } \\
\text { Planning }\end{array}$ & $\begin{array}{l}\text { Large Enterprise } \\
\text { (LE) }\end{array}$ & 4400 \\
\hline 7 & G & Hospital hardware & $\begin{array}{l}\text { Vice President of Global } \\
\text { Logistics }\end{array}$ & $\begin{array}{l}\text { Large Enterprise } \\
\text { (LE) }\end{array}$ & 6300 \\
\hline 8 & $\mathrm{H}$ & $\begin{array}{l}\text { Biological-derived } \\
\text { devices }\end{array}$ & $\begin{array}{l}\text { Manager of Global } \\
\text { Logistics }\end{array}$ & $\begin{array}{l}\text { Large Enterprise } \\
\text { (LE) }\end{array}$ & 600 \\
\hline 9 & I & $\begin{array}{l}\text { Non-active implantable } \\
\text { technology }\end{array}$ & $\begin{array}{l}\text { Vice President of Supply } \\
\text { Chain }\end{array}$ & $\begin{array}{l}\text { Small and Medium } \\
\text { Enterprise (SME) }\end{array}$ & 180 \\
\hline 10 & $\mathrm{~J}$ & $\begin{array}{l}\text { Electromechanical } \\
\text { medical technology }\end{array}$ & $\begin{array}{l}\text { Head of Supply Chain } \\
\text { Operations }\end{array}$ & $\begin{array}{l}\text { Small and Medium } \\
\text { Enterprise (SME) }\end{array}$ & 400 \\
\hline 11 & $\mathrm{~K}$ & $\begin{array}{l}\text { Diagnostic and } \\
\text { therapeutic radiation } \\
\text { technology }\end{array}$ & $\begin{array}{l}\text { Director of Supply Chain } \\
\text { Management }\end{array}$ & $\begin{array}{l}\text { Large Enterprise } \\
\text { (LE) }\end{array}$ & 49000 \\
\hline 12 & $\mathrm{~L}$ & Single use technology & Director of Supply Chain & $\begin{array}{l}\text { Small and Medium } \\
\text { Enterprise (SME) }\end{array}$ & 500 \\
\hline 13 & M & $\begin{array}{l}\text { Healthcare facility } \\
\text { products and systems } \\
\text { adaptations }\end{array}$ & Head of Supply Chain & $\begin{array}{l}\text { Small and Medium } \\
\text { Enterprise (SME) }\end{array}$ & 200 \\
\hline 14 & $\mathrm{~N}$ & $\begin{array}{l}\text { Anaesthetic and } \\
\text { respiratory technology }\end{array}$ & $\begin{array}{l}\text { Director of Purchasing, } \\
\text { Global Supply Chain }\end{array}$ & $\begin{array}{l}\text { Small and Medium } \\
\text { Enterprise (SME) }\end{array}$ & 200 \\
\hline 15 & $\mathrm{O}$ & Hospital hardware & $\begin{array}{l}\text { Head of Outbound } \\
\text { Logistics }\end{array}$ & $\begin{array}{l}\text { Large Enterprise } \\
\text { (LE) }\end{array}$ & 15200 \\
\hline
\end{tabular}

\section{Table 2: Summary of the respondent demographics}

$1=($ GMDN-Agency, 2012)

2=(Institut für Mittelstandsforschung (IfM), Bonn, 2017)

The primary data collection utilised semi-structured interviews (see Appendix I).

Following Yin (2009), tests for construct validity, internal validity, external validity and reliability were performed. Table 3 below summarises all four tests and tactics adopted to ensure validity and reliability. 


\begin{tabular}{|ll|}
\hline Tests & Case study tactic \\
\hline Construct validity & - Use multiple sources of evidence \\
& - Chain of evidence \\
& - Have respondents review draft case study report \\
Internal validity & - Use pattern matching \\
& - Address rival explanations \\
External validity & - Use replication logic \\
Reliability & - Use interview protocol \\
\hline
\end{tabular}

Table 3: Case study design considerations - adapted from Yin (2009, p. 41)

To ensure construct validity, multiple sources of evidence, chain of evidence, and informant reviews were used (Yin, 2009). The main respondents of each interview were the heads of SCM or other high-level executives. All 15 organisations represented OEMs from the German Medical Technology sector, but of variable size and specific products.

For triangulation, qualitative and qualitative archival data in the form of company documentation (e.g. reports, procedures) and as well as publicly available material (e.g. annual reports, corporate websites) were collected and analysed. To ensure consistency during the application of the method, all interviews were arranged, conducted and summarised by the researchers. Following Robson (2011), interviews took no longer than 45 minutes and permission was sought from each participant to use a tape-recorder to record the interview. Once the data were summarised, they were sent back to each one of the organisations for review. Based on the feedback received from the respondents, minor changes were made to the interview data. The interview data were then translated from German into English. Confidentiality was an important prerequisite for all interviews and efforts were made to ensure 
it. Permission was granted by the organisations involved to employ the interview data for analysis.

In an effort to avoid researcher bias and increase internal validity, the authors shared the results during the course of the study among themselves and with their colleagues. The analysis of the case study data entailed the identification of patterns in the different cases and explaining why these patterns existed (Yin, 2009). Efforts were also made to address rival explanations.

Replication logic was utilised in order to establish the domain to which a study's findings could be generalised. Yin (2009) recommends using replication via multiple case design. The case studies characterised a wide range of companies, products, and services (Table 2). Instead of being limited to representing 15 data points in a quantitative study, each one of these case studies represented an experiment of its own (Yin, 2009; Ellram, 1996). Each of these organisations conducted SCM activities with several degrees of success and under many different conditions in order to improve their competitiveness. Regardless of their degree of success, a cross-case analysis made apparent that there are commonalities among the CSFs.

Every step in the process was documented -interviews, data coding, details of any triangulation analysis, and the steps towards generalisation (Yin, 2009). The case study protocol for the study was designed with the support of academics and colleagues, and adjusted with insights generated after the conclusion of the pilot phase. Notes, documents, tabular materials, and narratives constitute the elements of a case study database.

\subsection{Data Analysis}

Analysis and interpretation of field data are considered the core of theory building of case studies. Nonetheless, they constitute the most difficult part of the process (Eisenhardt, 1989), 
as all data should be treated without bias while preserving their original meaning and context (Yin, 2009). The data analysis was conducted in two steps: within case and cross-case. All interviews were analysed following the three-step approach of Miles and Huberman (1994): data reduction, data display, and conclusion.

Initial conclusions for each case were generated and documented separately. After individual firm profiles were obtained from within-case coding, a cross-case analysis was conducted (Yin, 2009). Data were reduced to quotes, sentences and/or paragraphs that proved relevant to the research question (raw data themes). The raw data themes were clustered into descriptive high order themes such as 'patient safety', 'forecast accuracy and accountability', 'capacity allocation', among others. This allowed the researchers to identify major themes that served as a first indication of general issues considered important by the interviewed organisations, and to identify commonalities and differences between them. Furthermore, these major themes enabled the researchers to identify patterns and deduce general dimensions. Excerpts of the indepth analysis are found in Table 4, demonstrating how the researchers progressed from raw data themes over descriptive codes (higher order themes) to deducing CSFs grounded in and deduced from the SCM literature. Coding was only regarded as complete once agreement between researchers was reached.

\begin{tabular}{|c|c|c|}
\hline Raw data themes & Codes & $\begin{array}{c}\text { Main themes } \\
\text { (CSFs) }\end{array}$ \\
\hline "Decisions regarding supply chain capacity allocation usually lead to very \\
intensive discussions in the management team, particularly as there are still \\
issues to solve in regard to our current approach to reviewing our forecasts \\
on a quarterly basis. We are knowingly (or to some extent unknowingly) \\
$\begin{array}{l}\text { assigning tightly constrained resources to tasks that we already know today } \\
\text { will not be next month's priority, or even next week's. Marketing and sales } \\
\text { and operations do not usually trust each other's figures, leading to more } \\
\text { tension and counterproductive behaviours." (Company G) }\end{array}$ & decision & Sales and \\
\hline
\end{tabular}




\begin{tabular}{|c|c|c|}
\hline Raw data themes & Codes & $\begin{array}{c}\text { Main themes } \\
\text { (CSFs) }\end{array}$ \\
\hline $\begin{array}{l}\text { "Teams in our design department are typically assessed on their speed in } \\
\text { bringing a new product, technology, or customer service to the market, and } \\
\text { on budget. It really comes down to two measures of success: speed and } \\
\text { turnover." (Company D) }\end{array}$ & $\begin{array}{c}\text { Measures of } \\
\text { success }\end{array}$ & $\begin{array}{l}\text { Product } \\
\text { development } \\
\text { process }\end{array}$ \\
\hline $\begin{array}{l}\text { "The supply chain organisation at corporate level has a tendency to point its } \\
\text { finger at marketing and sales and saying 'if you provided us with a more } \\
\text { accurate forecast, we could run better operations and a better supply chain.' } \\
\text { What it is often left out of the picture is that there will always be a margin of } \\
\text { forecast error. If the best we can achieve is } 60 \text { per cent forecast accuracy, } \\
\text { then marketing and sales should be held accountable for } 40 \text { per cent of } \\
\text { forecast error, but this is not done at all. If we had a fixed agreement on this, } \\
\text { we could design our supply chain to be flexible enough to adjust to a } 40 \text { per } \\
\text { cent forecast error rate." (Company B) }\end{array}$ & $\begin{array}{l}\text { Forecast } \\
\text { accuracy }\end{array}$ & $\begin{array}{c}\text { Sales and } \\
\text { operations } \\
\text { planning }\end{array}$ \\
\hline $\begin{array}{l}\text { "Obviously our major target is to ensure that all the products we develop, } \\
\text { manufacture and distribute to our customers are safe, user-friendly, and } \\
\text { compliant with FDA regulations. Regulations are strict, and it really doesn 't } \\
\text { take a rocket scientist to figure out why. When people's lives are at stake, the } \\
\text { appropriate tests must be strictly carried out. Observing safety compliance } \\
\text { in product design is not enough: we need to make sure that we are meeting } \\
\text { safety requirements at all steps of value creation". } \\
\text { (Company J) }\end{array}$ & Patient safety & $\begin{array}{l}\text { Quality and } \\
\text { compliance }\end{array}$ \\
\hline $\begin{array}{l}\text { "Adding value is not always about meeting all customer demands at any time } \\
\text { and at any price. It 's also about having a formal agreement with the customer } \\
\text { on terms and conditions. It's about managing customer expectations when it } \\
\text { comes to our products and services. It's about making sure that well-intended } \\
\text { people in the sales department don't unnecessarily increase the complexity } \\
\text { of operations for the design, scheduling, purchasing, production, and } \\
\text { logistics departments." (Company D) }\end{array}$ & $\begin{array}{l}\text { Management } \\
\text { of customers' } \\
\text { expectations }\end{array}$ & $\begin{array}{l}\text { Customer } \\
\text { relationship } \\
\text { management }\end{array}$ \\
\hline
\end{tabular}

Table 4: Excerpts from coding

\subsection{Pilot Study}

Before beginning the main study, a pilot study was developed and conducted in order to explore topical and methodological issues, generate conceptual clarification for the research design, sharpen the focus of the research investigation, and test the effectiveness of the field procedures (Yin, 2009). It was not intended as a pre-test, but rather to assist the researchers in the fine 
tuning of the planned lines of questions for the interview (Robson, 2011). Interviews were originally chosen as the main data collection method, which were conducted using a previous version of the questionnaire shown in Appendix 1. The interviews were piloted first with three participants of the $11^{\text {th }}$ Innovation Transfer Operations System (ITOS) Summit celebrated in the spring of 2013 in Remscheid, Germany, where they were asked questions related to their supply chain activities. The summit helped to identify 15 respondents for the pilot study, all representing organisations from the medical technology sector in Europe and headquartered not only in Germany but also in Sweden and France.

The pilot study was employed to streamline the research aim and to modify the questionnaire tool. One major change was related to the context of the case study. For practical reasons, it was decided to sharpen the focus of this research investigation to German OEMs of the medical technology sector located in Germany, as this study was originally intended to be conducted all over Europe. This modification benefited the overall results of the study, as it strengthened the conclusions generated after cross-case analysis in later stages of the study. The pilot study also contributed to the identification of several issues regarding the research approach. First, it confirmed that the interview approach, while time-consuming, was an appropriate method for this investigation, as face-to-face contact with the respondents and the on-site visits to each of the interviewed organisations appeared to be more meaningful than an anonymous survey approach. On the other hand, the total length of the interviews (over one hour in average) and the decrease of additional comments in the later questions suggested that the questionnaire should be shorter in order to encourage more meaningful answers. For this reason, the questionnaire tool was simplified to ensure that the total interview time would not exceed 45 minutes. This simplification was achieved by eliminating questions that delivered only straightforward answers or seemed confusing to the respondents of the pilot study. Finally, it 
was identified that only respondents that were contacted after the interview via telephone provided corrections or additions to the written summary of the interview. Respondents that were only contacted by email did not provide any feedback. Therefore efforts were made to contact all respondents during the main study via telephone.

The results of the pilot study were presented at the $21^{\text {st }}$ European Operations Management (Euroma) Conference on June $20^{\text {th }} 2014$ in Palermo, Italy (Garcia-Villarreal et al, 2014).

\section{Findings and Discussion}

Table 5 shows the Critical Success Factors that emerged from the analysis of data and compares them with extant literature on CSFs in the field of SCM. 15 CSFs were identified as a result of the cross-case coding process.

The six most important CSFs which emerged from this research and their implications are discussed in this section in detail.

\subsection{Joint decision making to match demand and supply with $S \& O P$}

Sales and operations planning is a both a cross-departmental and cross-organisational process that ranges over all operational areas of an organisation and requires inputs of both key supplier and customers (Sheldon, 2006). Sales and operations planning, if done right, improves end-toend supply chain performance (Sheldon, 2006). It is a process working twofold: it first creates a good overview of future demand trends on the basis of a demand forecast and using input from sales and key customers; then it develops a plan in order to match the forecast against the organisation's existing production and distribution capacities. Matching demand against capacities helps to identify potential constraints, which are then discussed by the management team until consensus is reached and solutions are agreed on (Aparajithan et al, 2011). The 
results are consolidated sales plans, production plans, inventory plans, new product development plans, strategic plans, and financial plans (Sheldon, 2006).

Nine out of the 15 case companies provided strong evidence to support this factor as critical for success. Managers of almost all interviewed organisations have launched in recent years or are conducting at the moment improvement projects on this area. For instance, Company $\mathbf{J}$ reported lower inventories and more stable production rates with shortened lead times as benefits of a launched project that took over 3 years to complete. Company B reported that the alignment of all information flows between sales, planning, production, logistics and expedition is essential in order to achieve a reliable sales and operations plan. Forecasting is a core activity of sales and operation planning. Company D developed a tool to compare the current forecast plan with the available capacity budget of all business units, avoiding production bottlenecks, minimising the cost of unsold goods, and increasing on-time delivery to the end customer. As pointed out by Company $\mathrm{O}$, structure, rigour, and the appropriate information platform are required for a functional S\&OP process. Here, they set up meetings with clearly defined responsibilities, increased executive participation and visibility, as well as an information management tool that allowed them to gather and feed the appropriate inputs to the process. Company $\mathrm{M}$ reported on how top management participation in the process is essential for its success, as a final and timely decision on conflicting issues is often required in order to produce consensus on the plan. Company $\mathrm{M}$ also developed a standard set of rules, common performance indicators and appropriate incentives for all business units in order to improve the forecast accuracy and increase accountability in case of deviations. Sales and marketing play an important role to generate a more accurate sales and operations plan. After reaching the limits of its postponement strategy for customised products, Company E focused 
on improving their pre-sale processes in an effort to offer end customers products that were easier to configure and to manufacture. 


\begin{tabular}{|c|c|c|c|}
\hline Critical Success Factor & Description & $\begin{array}{c}\text { No. of Respondents } \\
\text { (Company) }\end{array}$ & Support from SCM literature \\
\hline $\begin{array}{l}\text { Top management } \\
\text { support }\end{array}$ & $\begin{array}{l}\text { Top level management support is required to design and implement appropriate changes in the supply chain, as } \\
\text { decision makers at board level are more aware of an organisation's strategic imperatives to remain competitive in } \\
\text { the marketplace. Top management supports process improvements by committing time, personnel, and financial } \\
\text { resources as well as by building commitment across all relevant functions (Power et al, 2001; Gunasekaran \& } \\
\text { Ngai, 2003; Chen \& Paulraj, 2004). }\end{array}$ & $\begin{array}{c}4 \\
(\mathrm{~B}, \mathrm{H}, \mathrm{K}, \mathrm{M})\end{array}$ & $\begin{array}{l}\text { (Talib \& Hamid, 2014), (Cai et al, 2003), } \\
\text { (Chen \& Paulraj, 2004), (Chiu, 1995), (Dinter, 2012), } \\
\text { (Gunasekaran \& Ngai, 2003), } \\
\text { (Hu \& Hsu, 2010), (Lin et al, 2013), } \\
\text { (Ngai et al, 2004), (Ogden, 2006), } \\
\text { (Pettit \& Beresford, 2009), (Power et al, 2001), } \\
\text { (Soin, 2004), (Thakkar et al, 2013) }\end{array}$ \\
\hline $\begin{array}{l}\text { Sales and operations } \\
\text { planning }(\mathrm{S} \& \mathrm{OP})\end{array}$ & $\begin{array}{l}\text { Sales and operations planning helps decision makers to determine how much of which products to make, where } \\
\text { to make them, and in which markets to distribute them based on demand forecasts, cost factors, and strategic } \\
\text { objectives. S\&OP supports strategic decision making on how to allocate supply chain capacity. It requires an } \\
\text { appropriate information flow, segmentation of products and customers based on demand patterns, and leaders' } \\
\text { commitment to encouraging and modelling the right behaviours (Sheldon, 2006; Aparajithan et al, 2011). }\end{array}$ & $\begin{array}{c}9 \\
(\mathrm{~B}, \mathrm{D}, \mathrm{G}, \mathrm{H}, \mathrm{I} \\
\mathrm{J}, \mathrm{K}, \mathrm{M}, \mathrm{O})\end{array}$ & $\begin{array}{l}\text { (Chiu, 1995), } \\
\text { (Gunasekaran \& Ngai, 2003), } \\
\text { (Gunasekaran \& Ngai, 2004), } \\
\text { (Thakkar et al, 2013), }\end{array}$ \\
\hline
\end{tabular}




\begin{tabular}{|c|c|c|c|}
\hline Critical Success Factor & Description & $\begin{array}{c}\text { No. of Respondents } \\
\text { (Company) }\end{array}$ & Support from SCM literature \\
\hline $\begin{array}{l}\text { Information } \\
\text { management }\end{array}$ & $\begin{array}{l}\text { Appropriate information systems support decision making in SCM in different ways, for instance, gathering and } \\
\text { supporting the analysis of historical information (products, quantities, prices, suppliers,...), establishing } \\
\text { appropriate metrics to measure supply chain performance, visualising expenditures across the supply chain, } \\
\text { supporting standardisation efforts, among others. Web-based information systems in SCM reduce communication } \\
\text { barriers among actors of the supply chain, thus enabling integration and support more accurate customer or } \\
\text { supplier profiling. Conversely, information management systems are regarded as a main barrier in supply chain } \\
\text { collaboration, due to incompatibility of IT applications among supply chain partners or inconsistent information } \\
\text { (Gunasekaran \& Ngai, 2003; Chen \& Paulraj, 2004; Ogden, 2006; Dinter, 2012). }\end{array}$ & $\begin{array}{c}2 \\
(\mathrm{~B}, \mathrm{M})\end{array}$ & $\begin{array}{l}\text { (Talib \& Hamid, 2014), (Chen \& Paulraj, 2004), } \\
\text { (Cullen \& Taylor, 2009), (Dinter, 2012), } \\
\text { (Gunasekaran \& Ngai, 2003), } \\
\text { (Gunasekaran \& Ngai, 2004), (Kim \& Rhee, 2012), } \\
\text { (Koh et al, 2011), (Lin et al, 2013), } \\
\text { (Mothilal et al, 2012), } \\
\text { (Gunasekaran, \& Nachiappan, 2012), } \\
\text { (Ngai et al, 2004), } \\
\text { (Ogden, 2006), (Pettit \& Beresford, 2009), } \\
\text { (Power et al, 2001), (Soin, 2004), } \\
\text { (Thakkar et al, 2013), } \\
\text { (Tummala et al, 2006), } \\
\text { (Wu \& Hsu, 2009) }\end{array}$ \\
\hline Procurement strategies & $\begin{array}{l}\text { Strategic purchasing is considered critical for the success of SCM, as purchasing decisions strongly impact } \\
\text { strategic planning due to the quickly fluctuating competitive environment. Selecting appropriate suppliers entails } \\
\text { choosing suppliers that can meet the needs of the organisation in terms of capacity, lead times, quality, } \\
\text { manufacturing technology, price, service, among other criteria. Strategic purchasing is reported by literature as a } \\
\text { condition to establish cooperative supplier relationships in order to enhance a firm's competitive position. } \\
\text { Furthermore, reducing the number of suppliers may prove beneficial to organisations, as win-win relationships } \\
\text { can be developed with remaining suppliers, increasing leverage for the organisation (Power et al, 2001; Chen \& } \\
\text { Paulraj, 2004; Ogden, 2006; Kim \& Rhee, 2012). }\end{array}$ & $\begin{array}{c}5 \\
(\mathrm{C}, \mathrm{D}, \mathrm{J}, \mathrm{K}, \mathrm{O})\end{array}$ & $\begin{array}{l}\text { (Chen \& Paulraj, 2004), (Hu \& Hsu, 2010), } \\
\text { (Lin et al, 2013), (Kim \& Rhee, 2012), } \\
\text { (Koh et al, 2011), (Mothilal et al, 2012), } \\
\text { (Ogden, 2006), (Power et al, 2001), } \\
\text { (Soin, 2004), (Thakkar } \text { et al, 2013) }\end{array}$ \\
\hline
\end{tabular}




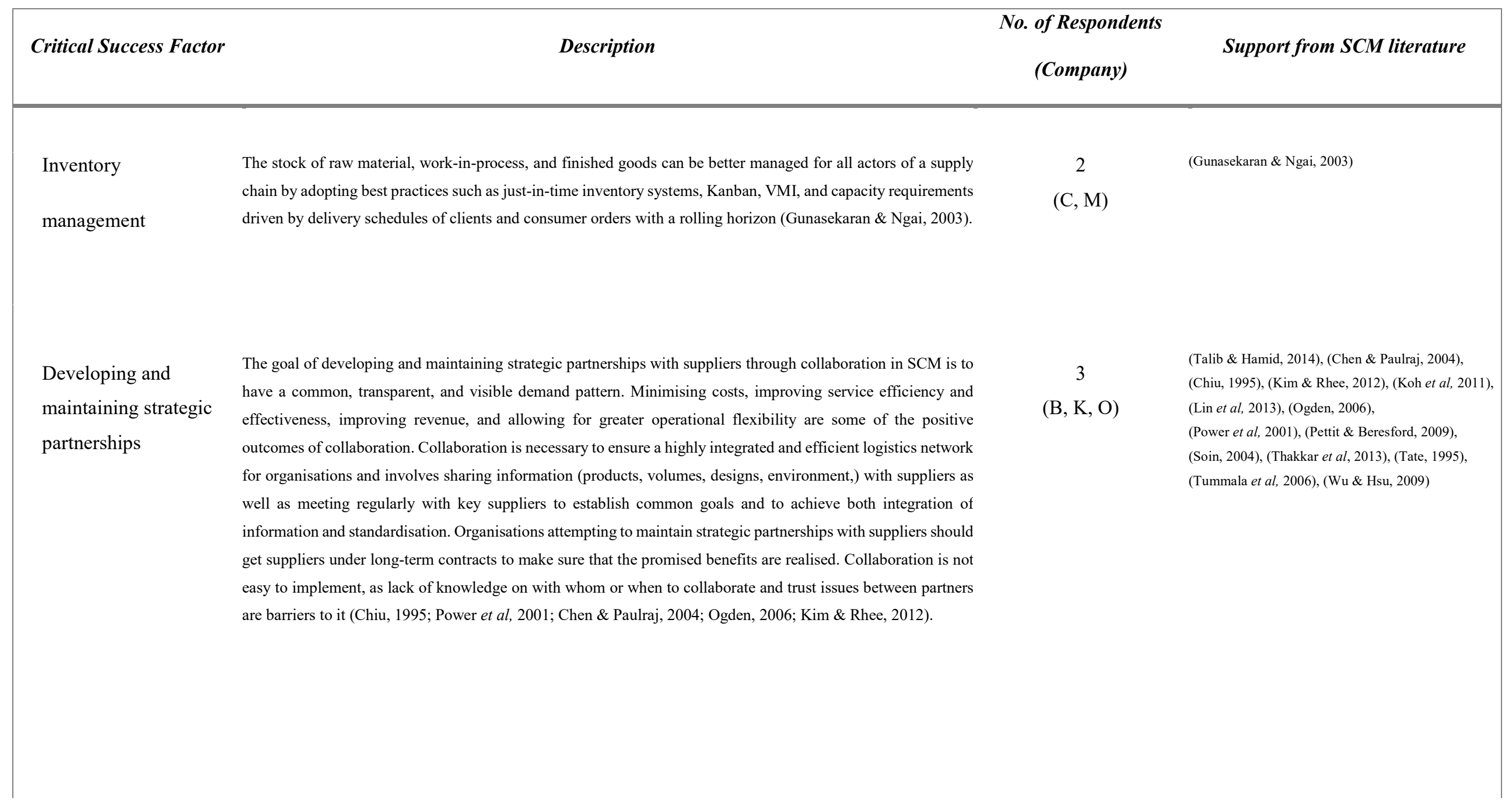




\begin{tabular}{|c|c|c|c|}
\hline Critical Success Factor & Description & $\begin{array}{c}\text { No. of Respondents } \\
\text { (Company) }\end{array}$ & Support from SCM literature \\
\hline Production system & $\begin{array}{l}\text { A production system allows an organisation to produce more products in the same or shorter time while ensuring } \\
\text { the expected quality with less cost. A supply chain can benefit from shorter work cycles and from the elimination } \\
\text { or reduction of all non-added value activities, as it increases the responsiveness of a supply chain to changes in } \\
\text { the demand. A key concept in production systems relates to competitive priorities, in which manufacturing } \\
\text { companies decide which manufacturing tasks or key competitive capabilities should be kept in-house. Decisions } \\
\text { at this level are made based on cost, flexibility, quality, and delivery capabilities. The overall supply chain strategy } \\
\text { can be benefited when decisions are not purely based on cost, but also on issues of flexibility, quality, innovation, } \\
\text { speed, time, and dependability (Schönheit, 1997; Tummala et al, 2006; Koh et al, 2011). }\end{array}$ & $\begin{array}{c}5 \\
(\mathrm{~A}, \mathrm{~B}, \mathrm{C}, \mathrm{D}, \mathrm{H})\end{array}$ & $\begin{array}{l}\text { (Koh et al, 2011), } \\
\text { (Tummala et al, 2006) }\end{array}$ \\
\hline $\begin{array}{l}\text { Product development } \\
\text { process }\end{array}$ & $\begin{array}{l}\text { Decisions made during product design and development have an influence on the setup and degree of complexity } \\
\text { of the supply chain that is required to support their delivery. The influence of product development is not only } \\
\text { related to shorter time to market of products or more robust processes, but also to shorter production cycles for } \\
\text { serial parts at the OEM production facilities. Benefiting from shorter lead times can be achieved through product, } \\
\text { components, and production process standardisation. The role of physicians is also essential in device innovation, } \\
\text { with collaboration between developers and physicians being of great importance in order to both reduce the } \\
\text { complexity of production of devices and strengthen the relationship with the customer. Integration of suppliers in } \\
\text { new product development has also been reported as important, with support ranging from giving minor design } \\
\text { suggestions to being responsible for the complete design, development, and engineering of specific parts (Wu \& } \\
\text { Hsu, 2009). }\end{array}$ & $\begin{array}{c}7 \\
(\mathrm{~A}, \mathrm{D}, \mathrm{E}, \mathrm{H}, \mathrm{I}, \mathrm{J}, \mathrm{O})\end{array}$ & (Wu \& Hsu, 2009) \\
\hline
\end{tabular}




\begin{tabular}{|c|c|c|c|}
\hline Critical Success Factor & Description & $\begin{array}{c}\text { No. of Respondents } \\
\text { (Company) }\end{array}$ & Support from SCM literature \\
\hline $\begin{array}{l}\text { Training and } \\
\text { commitment of } \\
\text { staff }\end{array}$ & $\begin{array}{l}\text { Training and experience of staff is an important issue in SCM, as having strategic thinkers and individuals with } \\
\text { knowledge about the product and the marketplace lead to better results in strategic and operational decisions. } \\
\text { Commodities should be managed by people knowledgeable of the product. In order to increase stakeholder buy- } \\
\text { in, cross-functional, autonomous teams are important, as they enhance the probability of stakeholders participating } \\
\text { in the entire process, thus hindering thinking and acting in silos. Thus, stakeholders in a supply chain are more } \\
\text { likely to approve changes when they provide input in shaping SC strategies (Ngai, Cheng, \& Ho, 2004; Ogden, } \\
\text { 2006). }\end{array}$ & $\begin{array}{c}4 \\
(\mathrm{~A}, \mathrm{D}, \mathrm{M}, \mathrm{O})\end{array}$ & $\begin{array}{l}\text { (Talib \& Hamid, 2014), (Cai et al, 2003), } \\
\text { (Lin et al, 2013), (Ngai et al, 2004), (Ogden, 2006), } \\
\text { (Pettit \& Beresford, 2009), (Power et al, 2001), } \\
\text { (Thakkar et al, 2013) }\end{array}$ \\
\hline $\begin{array}{l}\text { Quality and } \\
\text { compliance }\end{array}$ & $\begin{array}{l}\text { Safety and effectiveness of products are important issues for the Medical Technology sector. Companies must } \\
\text { both validate their products and manufacturing practices in order to remain in the business. Agencies such as the } \\
\text { U.S. Food and Drug Administration (FDA) are responsible of ensuring that manufacturers and products comply } \\
\text { with current medical device laws. This becomes an important issue for SCM and poses a challenge for } \\
\text { manufacturers, as they must satisfy the high demands on quality, traceability, and security. (BVMed, 2015; FDA, } \\
\text { 2014; Kuei \& Madu, 2008). }\end{array}$ & $\begin{array}{c}7 \\
(\mathrm{C}, \mathrm{D}, \mathrm{F}, \mathrm{G}, \mathrm{J}, \mathrm{M}, \mathrm{N})\end{array}$ & (Kuei \& Madu, 2008) \\
\hline
\end{tabular}




\begin{tabular}{|c|c|c|c|}
\hline Critical Success Factor & Description & $\begin{array}{l}\text { No. of Respondents } \\
\text { (Company) }\end{array}$ & Support from SCM literature \\
\hline $\begin{array}{l}\text { Customer relationship } \\
\text { management }\end{array}$ & $\begin{array}{l}\text { Customer relationship management is deployed to ensure that there is no gap between customer expectations and } \\
\text { requirements and the delivery of products and services by the organisation in focus, so that these items can be } \\
\text { made available on time as required. This entails forming strategic alliances with the customer, setting up frequent } \\
\text { meetings between suppliers and customers, and shared information systems (Chen \& Paulraj, 2004; Lin et al, } \\
\text { 2013). }\end{array}$ & $\begin{array}{c}5 \\
(\mathrm{~A}, \mathrm{D}, \mathrm{K}, \mathrm{M}, \mathrm{O})\end{array}$ & $\begin{array}{l}\text { (Chen \& Paulraj, 2004), (Kuei \& Madu, 2008), } \\
\text { (Lin et al, 2013), (Soin, 2004), } \\
\text { (Tate, 1995) }\end{array}$ \\
\hline Distribution system & $\begin{array}{l}\text { A distribution strategy incorporates interactions among several actions in a supply chain. Each focal organisation } \\
\text { has got its own unique network comprising of different actors, resources, and activities, both downstream and } \\
\text { upstream. The position of each company in the supply chain with respect to others reflects on its capacity to } \\
\text { provide value to others (e.g. innovation, productivity, flexibility, competence). A supply network structure is } \\
\text { influenced by several factors, such as the task, authority issues, and coordination mechanisms across several firms } \\
\text { or organisational units (Chen \& Paulraj, 2004; Gunasekaran \& Ngai, 2003; Thakkar et al, 2013). }\end{array}$ & $\begin{array}{c}3 \\
(\mathrm{~K}, \mathrm{~L}, \mathrm{M})\end{array}$ & $\begin{array}{l}\text { (Chen \& Paulraj, 2004), (Chiu, 1995), } \\
\text { (Gunasekaran \& Ngai, 2003), } \\
\text { (Lao et al, 2011), } \\
\text { (Thakkar et al, 2013), }\end{array}$ \\
\hline Transport management & $\begin{array}{l}\text { Transport management influences the downstream, door-to-door operational processes of a supply chain and } \\
\text { involves the core processes of shipping, forwarding, (de)consolidation, contract delivery, freight bill payment, } \\
\text { warehousing, relocation, load tendering, and brokering Appropriate decisions regarding outsourcing this function } \\
\text { or keeping it in the core business of an organisation can improve competitive advantage (Gunasekaran \& Ngai, } \\
\text { 2003). }\end{array}$ & $\begin{array}{c}4 \\
(\mathrm{~A}, \mathrm{D}, \mathrm{E}, \mathrm{H})\end{array}$ & $\begin{array}{l}\text { (Chiu, 1995), (Gunasekaran \& Ngai, 2003), } \\
\text { (Pettit \& Beresford, 2009), } \\
\text { (Thakkar } \text { et al, 2013) }\end{array}$ \\
\hline
\end{tabular}




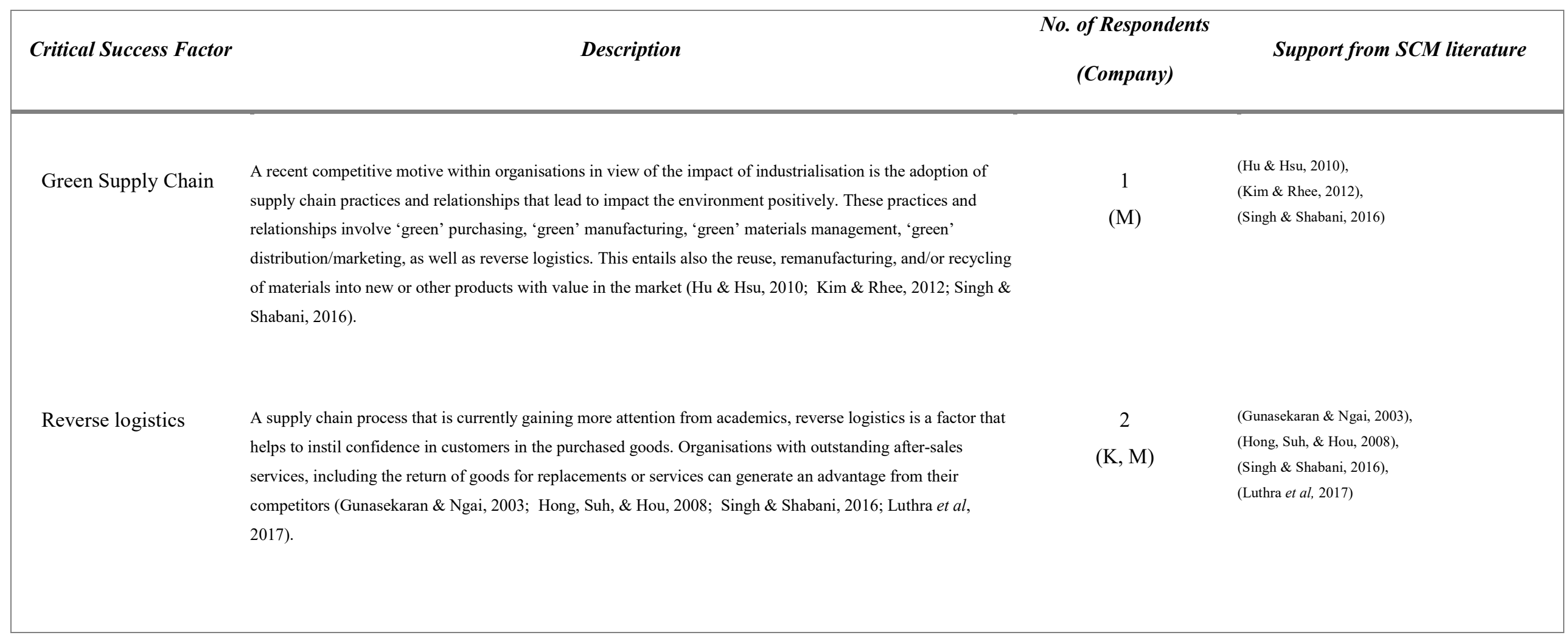

Table 5: CSFs related to the respondents' perception 
One major barrier to implement a robust S\&OP process is the 'silo-mentality' prevalent in organisations, where the targets of sales departments are at odds with the targets of operations (Sheldon, 2006). In order to free themselves from this barrier, Company O developed joint sales and operations goals and had the sales and production teams share the same workspace in order to encourage the right behaviours in the organisation.

Regardless of their size and product range, the nine respondents considering this factor of critical importance face similar issues in terms of poor decision making and firefighting actions in order to balance demand and capacities. Major barriers reported were conflicting targets within departments, poor master data quality, poor organisation of the master scheduling department, a lack of measurement of forecast quality, and planning with infinite capacities as a general approach.

Based on the results of the analysis, we propose that:

P1 Issues of balancing customer demand requirements and capacity allocation in the supply chain are raised by conflicting goals between departments within an OEM and between organisations in the supply chain of German MT. OEMs focusing on installing sustainable and robust Sales and Operation Planning systems have a competitive advantage over those who do not.

\subsection{Reduction of complexity in the design of products and manufacturing processes}

Medical Technology is one of the most research-intensive industries in Germany (BMBF, 2017). The basis for the economic success of Medical Technology in Germany and abroad is the broad range of innovative products it creates. About a third of its revenues are generated from products that are less than three years old (BVMed, 2018). For this reason, 
the product development process becomes crucial for the supply of innovative products to an organisation's customers (Medina et al, 2013). Respondents consider this factor as highly critical, as the decisions made at the product development process stage account for $70-80 \%$ of the product's final costs (Schönheit, 1997; Handfield \& Nichols, 2002). In this context, designers play a major role (either consciously or unconsciously) in the setup of their supply chains and in their degree of complexity, but their influence is not only limited to the reduction of time to market with intelligent product design (Wu \& Hsu, 2009).

From an economic point of view, the risk of lost margin rises with the increase of exotic parts and special constructions that should be later catered by the supply chain (Schönheit, 1997). Company D observed this phenomenon in their own operations and transitioned from an inwardly oriented model (first developing a product then searching for a market) to a more customer oriented model of product design (understanding customer needs and developing strategies to promote their products) while reducing the diversity of their product variants. Involving users in the innovation process can be beneficial to an OEM, as development time, product test and regulatory approval time, as well as development costs can be reduced (Lettl, 2013). Given the importance of the role of users in the design of products, Company D cooperates actively with surgeons in the design of medical devices and names their finished products after the physician that inspired or co-designed them. Activities in product development process have an influence on the performance of other organisational functions, such as procurement, manufacturing, marketing and sales, and service (Schönheit, 1997). Company A launched a project to standardise information flows between sales, product development, and procurement in order to reduce the risk of increasing their dependency to niche suppliers by increasing their supplier base. These 
efforts enhanced their material availability while reducing the risk of material obsolescence. The results were an increase of their order fulfilment and on-time deliveries. Company $\mathbf{J}$ analysed their product portfolio in an effort to standardise their raw materials and their part numbers, with the effect of decreasing their supplier base and streamlining their purchasing, order picking, and assembly processes. Company D focused on reducing manufacturing costs (technology, methods, and materials) through a re-examination of their product portfolio. Finally, Company $\mathrm{H}$ launched a project to improve their product update services in order to cut manufacturing, procurement, inventory, and after-sales costs.

Six out of the 15 organisations interviewed have been actively working on shifting the focus from 'developing the best possible product' (Push) to 'designing the most adequate product for physicians' (Pull), an approach that required shifting paradigms present in German engineering organisations - getting away from a traditional engineer's mentality ('made in Germany') to a more customer-oriented and thus economically meaningful approach to design.

For these reasons, we propose that,

P2. In order to reduce complexity of future operations, product design requires not only the involvement of physicians, health institutions, and regulatory agencies to enhance product functionality, but also the involvement of stakeholders of the supply chain, particularly manufacturing, sourcing, logistics, sales, and after sales services. 


\subsection{Efficient tracking and tracing of Medical Technology in the supply chain brings competitive advantage}

The Medical Technology sector is in a high pressure to deliver products that are safe and effective for patients. Agencies such as the U.S. Food and Drug Administration (FDA) are responsible of ensuring that manufacturers and products comply with current medical device laws (FDA, 2014). Due to the high demands regarding quality, traceability, and security, organisations are requested to deliver documented evidence that the quality criteria regarding processes and products have been fulfilled (BVMed, 2015) and that all manufactured parts can be re-traced, thus becoming an important issue in SCM.

A factor rarely found in the reviewed SCM literature, 'quality and compliance' was regarded as critical for success by seven of the case study companies. Manufacturers of medical devices must ensure that their products do not put the lives of patients at risk. Audits and certifications are common instruments to promote quality design and manufacturing practices (FDA, 2014). National and international guidelines and laws also foresee the validation and qualification of systems (BVMed, 2018). Many decisions in SCM are influenced by these regulations, as errors can occur during the development, production, sterilisation, storage, transportation or utilisation of medical devices (Marucheck et al, 2011). Company F reports on the many measures they must take in order to avoid contamination or inadequate sterilisation during packaging, transportation, and handling. Decisions are also taken at a slower rate as in other industries. Company $\mathrm{H}$ noted that decisions to expand critical manufacturing capacities or launching continuous improvement activities on the shop floor are, in comparison with other industries, at a much slower pace and subject to more detailed scrutiny before rollout. Company I reported on the pressures to balance the construction of new, innovative products that 
meet market requirements while complying with costly and time-consuming (but necessary) regulations.

Given the critical nature of medical devices and the potential harm failures during the production and distribution processes can cause, implementing effective tracking and traceability processes is critical. Companies $\mathrm{G}, \mathrm{H}$, and $\mathrm{N}$, all have designed, formalised, and validated processes and set up information management systems in line with the current technological trend of 'Industry 4.0'. These systems are capable of collecting information and keeping track of products at all the stages of the supply chain (primary production by suppliers, incoming material, warehousing, production and assembly, sterilisation, warehousing, distribution, and utilisation by the customer) and represent an improvement over previous processes, which were characterised as being bureaucratic, time-consuming, inefficient, and employing manual systems. This turned into an advantage for these companies, as the regulatory requirements of the countries in which they sell their devices may vary and the timeliness and transparency of information is a decisive factor in this market. This, however, proved to be a very time consuming and costly exercise for Company M, a SME, which after three years of switching into a new information management system, has not benefited from this implementation. The authors propose that a future process flow design is an imperative requirement to determine which digital tools are required and valued by the customer (e.g. hospitals and clinics) and worth investing in and how much improvement potential is existent in order to reduce overhead cost in supply chain operations. 
With these insights in mind, we propose that:

P3. As supply chain visibility is a capability that customers are increasingly willing to pay for, selecting the appropriate tools requires process orientation. Providing hospitals and clinics with real-time information on product and spare parts shipping status can provide a competitive advantage for OEMs in the Medical Technology sector.

\subsection{Increasing leverage of OEMs with appropriate procurement strategies}

Both purchasing and materials management constitute basic strategic business processes critical for the success of SCM and not just a narrow support function to the overall business strategy (Reck et al, 1992). Although studies such as Bhakoo and Chan (2011) have investigated collaboration and e-commerce within healthcare, the Medical Technology devices has not been the focus. Purchasing portfolio models have recently become very popular in the field of professional purchasing (Caniels \& Gelderman, 2005), with Kraljic's model for developing supply strategies (Kraljic, 1983) being one of the most known. In this model, organisations develop purchasing strategies based on their own strength and the strength of the supply market, resulting in three general purchasing strategies: exploit (in the case of buyer dominance), balance (in the case of a balanced relationship), or diversify (in case of supplier dominance) (Kraljic, 1983; Reck et al, 1992).

In the context of supply chain management, the employed procurement strategies play a major role in the creation of value for industries in the Medical Technology sector, as 
medical devices have a relatively short life cycle in comparison with products from other industries (Thomas \& Griffin, 1996). Company C developed an integrated approach towards procurement based on the phases of the product life cycle. In the product development phase, the focus of the purchasing department lies on the preselection of suitable suppliers and on the research of substitution materials while the $R \& D$ department focuses on designing modular products (Baukastenprinzip). During product market launch, procurement, product development, and logistics join efforts to ensure minimal stock and foster collaboration with suppliers in both the design and delivery of components. During market penetration, procurement has the tasks of searching for alternative suppliers in order to reduce the risk of stockouts. In the market saturation phase, the focus changes to cost optimisation through product standardisation and the arrangement of long-term contracts with suppliers. Finally, during product phase-out, the target of procurement and logistics is to minimise stock levels and avoiding material cost increases.

Conventional procurement strategies (VMI, EDI, Just in Time, Supplier Kanban) are applied by almost all of the large enterprises involved in this research. All Case companies note that it is important to evaluate procurement strategies from a holistic perspective and consider the impact these might have in other organisations in the supply chain. In this context, selecting the right supplier involves more than looking for a supplier that can deliver goods at the lowest cost per piece; it involves a combination of criteria such as right quality, sufficient capacity, appropriate lead times and technology, price, and additional services. Company $\mathrm{H}$ warns on using low cost country sourcing as a procurement strategy, as lost margin can be generated at the very beginning of a project 
when suppliers cannot deliver the agreed quality. Geographical distance, language and intercultural issues can also become barriers as well.

Power relationships also play a role in the selection of the appropriate suppliers in the Medical Technology sector. Case companies C, D, and K have implemented Just in Time strategies with several degrees of success as a means to reduce stocks, forcing their suppliers to deliver raw material and components in small quantities and on immediate basis. Furthermore, Case companies D, K, and $\mathrm{O}$ have implemented VMI, making suppliers responsible for both stock overflows and stock-outs of at the OEMs' warehouse facilities. In contrast, Companies L and M, both SMEs, are not strong enough to put pressure on suppliers to adopt such practices.

Hence, we propose that:

P4. Although procurement strategies such as VMI, Kanban, and JIT appear to be more beneficial for large German firms with power over suppliers, SMEs require their procurement strategies to be based on the product lifecycle in order to reduce the risk of inventory obsolescence. Cooperation and process knowledge exchange is beneficial for both OEMs and upstream organisations when designing and implementing alternative procurement strategies.

\subsection{CRM positively affects the configuration and complexity of SC operations}

Customer relationship management assists organisations in mining available customer data and information in order to understand customer requirements and to improve their value propositions. This involves collecting and logically using customer and other 
relevant data (the information process) to build a consistently superior customer experience and enduring customer relationships (Payne \& Frow, 2005). This involves an integration of processes, people, operations, and marketing capacities (Swift, 2000). Several respondents noticed that the relationship with end customers has turned more complex in recent years. For instance, Company $\mathrm{C}$ has noted a shift of the way they do business with their customers. In the past, they would show up directly at a hospital with a new product in hopes that it would enthuse physicians and purchasing managers with its features and, based on this, they would negotiate prices and number of units to deliver. Nowadays they must negotiate prices with intermediaries such as Group Purchasing Organisations (GPOs). Healthcare providers turn to GPOs in order to save time and money necessary to negotiate thousands of individual contracts (Supply Chain Association, 2015). This however, seems to make it harder for some of the interviewed OEMs to get first-hand information on customer needs, and on the side of the consumer, a greater role for physicians and governments has been considered necessary to ensure that technologies procured by GPOs best meet patient needs and are aligned with national health care priorities (Sorenson \& Kanavos, 2011). Several respondents considered this factor as a decisive point, as the success of their innovations depends on how well they understand their customers (both national and international customers), and the complexity of their supply chain depends, consequently, on the configuration of those innovations.

Company A recognised the importance of CRM and launched a project between sales, marketing, design and prototyping as well as representatives of the customer in order to generate a clear agreement and rules in the relationship with the end customer. To this effect, regular meetings with customers and shared information systems were key elements of this project. In this context, the role of the design department was highlighted 
as well, with customers (physicians) participating in the conception and design of new technologies. Company D's strategy towards more accurate demand forecasts involved the foundation of a strategic alliance with both physicians and healthcare providers. Based on these findings, authors suggest that CRM reduces the complexity of supply chain operations and can lead to new business models that German MT SMEs have yet to exploit.

For these reasons, we propose that:

P5. German Medical Technology OEMs require a shift from pure cost-orientation to service-orientation in order to remain competitive in the market. This is not limited to the strategic involvement of physicians and managers in issues such as product design, but also by designing and implementing tailor-made concepts for logistical supply and after sales services.

\subsection{Speed to market and better flexibility are imperative elements of the production system of Medical Technology OEMs}

The objective of an integrated production system is to produce more products in the same or shorter time with less cost while ensuring the expected quality. This is possible when work cycles are as short as possible and all non-added value activities are eliminated or at the very least, reduced. This results in shorter lead times, less work-in-process, and higher productivity for an organisation, which translates into a better responsiveness of its supply chain (Schönheit, 1997). Company D mentions that a key element to achieve agile, flexible supply chains is a production system that supports them, especially when several links of the supply chain belong to the same firm. Concentrating on changing previous management culture, refining target systems and ensuring process orientation 
within the organisation were the key elements of the implementation of their production system in several sites.

Focusing on added-value activities in the supply chain is critical and restructuring these activities can provide opportunities for improvement (Thomas \& Griffin, 1996). Company $\mathrm{M}$ was on the verge of losing a customer due to late deliveries. After the implementation of a Lean Production System in all of their manufacturing plants worldwide (an endeavour that took almost two years), the company was able to improve their on-time-delivery rates by $30 \%$ while reducing their fixed costs by $20 \%$.

Slow and long supply chains hinder a company's ability to respond quickly to customer demand and, as the life cycles of medical devices are very short, manufacturers face the risk of inventory obsolescence (Thomas \& Griffin, 1996; Li et al., 2008). For this reason, both Companies $\mathrm{C}$ and $\mathrm{H}$ have focused on improving material flow by streamlining their value streams starting from their suppliers to their distribution centres. They also have focused on carefully defining the information requirements between organisations and the instruments used to transfer this information. The results were overwhelming for both organisations: shorter delivery times, extra capacity for new orders, less stock between processes and a higher turnover rate of stored raw materials and components. However, the consequences of implementing a more agile production system should also be discussed and agreed with upstream business partners, as one-sided expectations of OEMs regarding inventory reduction at their level can bring about disruptions to their suppliers. Company $\mathrm{G}$ engaged in the transformation of its production system over a period of 30 months, resulting in an impressive reduction of lead times from 6 days to 1 day, a reduction of space requirements by $60 \%$, and a reduction of stocks by $30 \%$, all measures that decreased their customer order backlog dramatically. As their customer 
order backlog sunk and their inventory levels dropped down, Company G changed their behaviour of raw materials and components consumption, leading to more irregular demand schedules for three of its suppliers, who found themselves struggling to balance erratic demand changes with their manufacturing capacities.

Based on these findings, it is proposed that:

P6. Agile production systems that focuses on speed to market and flexibility are better suited to support German MT supply chains, as product life cycles are shorter than in other industries. However, consequences of these process changes should be agreed with upstream business partners in order to create win-win scenarios and long-lasting relationships.

\section{Conclusions}

MTSCs have received limited coverage in the existing SCM literature, subsumed by generic supply chain research interests. However, in light of the increasing recognition of the importance of healthcare systems, their efficiencies and effectiveness, MTCSs have a key contribution to make. This research is an initial attempt to contribute empirically and practically to not only the wider body of SCM literature, but also work on CSFs along with sectoral focus on medical technologies.

This paper's contribution to theory is threefold. Firstly, the findings indicate that there are six CSFs for German Medical Technology OEMs, prioritised as follows: (1) sales and operations planning, (2) product development process, (3) quality and compliance, (4)

procurement strategies, (5) customer relationship management, and (6) production 
systems. Secondly, the outcome of this study suggests that the combination of these CSFs leads to better performance of OEMs in the Medical Technology sector. CSFs have been the subject of previous research in the field of SCM but none has investigated the important and growing Medical Technology sector, which recent literature has labelled as 'supply chain laggards' (Mayr, 2013); this study provides elaboration and practitioner insight from the perspective of both LEs and SMEs of the German Medical Technology sector. Thirdly, this paper also clarifies a shift in our understanding of the importance of several CSFs to practitioners, such as information management and inventory management, which have been previously been perceived as more important than they actually are. Importantly, this study highlights pre-eminent factors for the success of SCM which have not been adequately recognised by previous research, in particular: quality and compliance, product development process, and production system.

Each of the identified CSFs is summarised in six testable propositions (Table 6). These propositions serve as a starting point for further scholarly inquiry into the supply chains of this industry sector. These propositions also show that in order to increase value for the OEMs of this sector, an integrated approach is essential. It is not the implementation of isolated projects that improves a supply chain, but rather the careful selection of the appropriate and targeted measures in order to allocate resources in a more efficient and effective way.

Research Propositions 
P1 Issues of balancing customer demand requirements and capacity allocation in the supply chain are raised by conflicting goals between departments within an OEM and between organisations in the supply chain of German MT. OEMs focusing on installing sustainable and robust Sales and Operation Planning systems have a competitive advantage over those who do not.

P2 In order to reduce complexity of future operations, product design requires not only the involvement of physicians, health institutions, and regulatory agencies to enhance product functionality, but also the involvement of stakeholders of the supply chain, particularly manufacturing, sourcing, logistics, sales, and after sales services.

P3 As supply chain visibility is a capability that customers are increasingly willing to pay for, selecting the appropriate tools requires process orientation. Providing hospitals and clinics with real-time information on product and spare parts shipping status can provide a competitive advantage for OEMs in the Medical Technology sector.

P4 Although procurement strategies such as VMI, Kanban, and JIT appear to be more beneficial for large German firms with power over suppliers, SMEs require their procurement strategies to be based on the product lifecycle in order to reduce the risk of inventory obsolescence. Cooperation and process knowledge exchange is beneficial for both OEMs and upstream organisations when designing and implementing alternative procurement strategies.

P5 German Medical Technology OEMs require a shift from pure cost-orientation to serviceorientation in order to remain competitive in the market. This is not limited to the strategic involvement of physicians and managers in issues such as product design, but also by designing and implementing tailor-made concepts for logistical supply and after sales services.

P6 Agile production systems that focuses on speed to market and flexibility are better suited to support German MT supply chains, as product life cycles are shorter than in other industries. However, consequences of these process changes should be agreed with upstream business partners in order to create win-win scenarios and long-lasting relationships.

Table 6: Research propositions

This paper provides empirical evidence about which strategies are being used by practitioners in the MT sector in order to improve the performance of their supply networks. Managers can use this work as a guideline to develop or restructure their own supply chain policies. The insights from the case study organisations documented in this research will be of interest to organisations both in and beyond this sector. The identified CSFs offer new priorities for management practice to consider, particularly if they are currently considering re-examining, adjusting or setting up new supply chain strategies. 
Furthermore, this work will potentially be relevant to those organisations operating in industries which are characterised by high regulation.

\section{Limitations and Future Research}

One limitation of this study is that the target group of the case study was the head of the SCM operation of each case company. Although researchers were involved in the discussions in order to overcome this limitation, the insights provided by this respondent group may not be representative of the perceptions of other stakeholders in the MTSC. An additional limitation is the fact that it only represents the context of German MTSCs. Future research into the Medical Technology sector should seek widening studies that include other countries in order to gain a better understanding of the Medical Technology supply chain as a whole and thus enhance the generalisability of the research findings. There is great scope for further research that would build upon work in this area. The first entails using the results of this research in order to compare and contrast MTSCs in the US and Japan - the other major global MTSCs. Such a study could assist in overcoming the lack of generalisability of this research and test the relationships established in this paper. Future research could also provide further investigation into the relationship between the identified CSFs and the results achieved after implementing strategies based on these factors. Further important work should test the six propositions advanced by this work. Finally, given the literature gap regarding CSFs in MTSCs, additional research could assist in providing further understanding of the drivers, barriers, processes and benefits within this context. 


\section{References}

Achanga, P., Shehab, E., Roy, R., \& Nelder, G. (2006). Critical success factors for lean implementation within SMEs. Journal of Manufacturing Technology Management, 17(4), pp. $460-471$.

Alazmi, M., \& Zairi, M. (2003). Knowledge Management Critical Sucess Factors. Total Quality Management, 14(2), pp. 199-204.

Antony, J., Leung, K., Knowles, G., \& Gosh, S. (2002). Critical success factors of TQM implementation in Hong Kong industries. International Journal of Quality \& Reliability Management, 19(5), pp. 551-566.

Ashby, A., Leat, M., \& Hudson-Smith, M. (2012). Making connections: a review of supply chain management and sustainability literature. Supply Chain Management: An International Journal, 17(5), 497-516.

Bakker, E., Zheng, J., Knight, L., \& Harland, C. (2008). Putting e-commerce adoption in a supply chain context. International Journal of Operations \& Production Management, 28(4).

Belassi, W., \& Tukel, O. I. (1996). A new framework for determining critical success/failure factors in projects. International journal of project management, 14(3), 141-151.

BMBF. (2005). Studie zur Situation der Medizintechnik in Deutschland im internationalen Vergleich. Berlin: Bundesministerium für Bildung und Forschung (BMBF).

BMBF. (2017). KMU-innovativ: Medizintechnik. Berlin: Bundesministerium für Bildung und Forschung (BMBF).

Boyer, K. K., \& Swink, M. L. (2008). Empirical Elephants - Why Multiple Methods are Essential to Quality Research in Operations and Supply Chain Management. Journal of Operations Management, 26(3), pp. 337-348.

Boynton, A. C., \& Zmud, R. W. (1984). An Assessment of Critical Success Factors. Sloan Management Review, 25(4), pp. 17-27.

Bräuninger, M., \& Wohlers, E. (2006). Medizintechnik in Deutschland - Zukunftsbranche Medizintechnik - Auch im Norden ein Wachstumsmotor. Hamburg - Kiel: HSH Nordbank AG .

Brown, A., Dixon, D., Eatock, J., Meenan, B., \& Young, T. (2008). A survey of success factors in new product development in the medical devices industry. Engineering Management Conference, (pp. 1-5).

Burns, L. (2000). A research agenda for health services management. Health Care Management Review, 25(4), 85-7.

Burns, L. R., DeGraaff, R. A., Danzon, P. M., Kimberly, J. R., Kissick, W. L., \& Pauly, M. V. (2002). The Wharton School Study of the Health Care Value Chain - The Health Care Value Chain: Producers, Purchasers and Providers. San Francisco: Jossey-Bass.

BVMed. (2015, April 13). BV Med - Über 25 Milliarden Euro Umsatz. Retrieved from http://www.bvmed.de/de/branche/wirtschaftskraft/produktion 
BVMed. (2018). Branchenbericht Medizintechnologien 2018. Berlin: Bundesverband Medizintechnologie (BVMed).

Cai, S., Jun, M., \& Kim, D. (2003). Critical Success Factors in Implementing Supply Chain Management: A Conceptual Model. Annual Meeting of the Decision Sciences Institute, (pp. 1951-1956). Washington.

Caniels, M. C., \& Gelderman, C. J. (2005). Purchasing Strategies in the Kraljic Matrix - A Power and Dependence Perspective. Journal of Purchasing and Supply Management, 11(2), pp. 141-155.

Chatterji, A. K. (2009). Spawned with a silver spoon? Entrepreneurial performance and innovation in the medical device industry. Strategic Management Journal, 30(2), pp. 185-206.

Chen, I. J., \& Paulraj, A. (2004). Towards a Theory of Supply Chain Management: The Constructs and Measurements. Journal of Operations Management, 22(2), pp. 119-150.

Cheng, C. C., \& Shiu, E. C. (2008). Critical Success Factors of New Product Development in Taiwan's Electronics Industry. Asia Pacific Journal of Marketing and Logistics, 20(2), pp. 174-189.

Chiu, H. N. (1995). The Integrated Logistics Management System: A Framework and Case Study. International Journal of Physical Distribution and Logistics Management, 25(6), pp. 4-22.

Cooper, M. C., \& Ellram, L. M. (1993). Characteristics of supply chain management and the implications for purchasing and logistics strategy. The International Journal of Logistics Management, 4(2), pp. 13-24.

Coronado, R. B., \& Antony, J. (2002). Critical success factors for the successful implementation of six sigma projects in organisations. The TQM Magazine, 14(2), pp. 92-99.

Cucchiella, F., \& Gastaldi, M. (2006). Risk management in supply chain: a real option approach. Journal of Manufacturing Technology Management, 17(6), 700-720.

Cullen, A. J., \& Taylor, M. (2009). Critical Success Factors for B2B E-Commerce Use Within the UK NHS Pharmaceutical Supply Chain. International Journal of Operations and Production Management, 29(11), pp. 1156-1185.

Dacosta-Claro, I. (2002). The performance of material management in health care organizations. International Journal of Health Planning and Management, 17(1), 69-85.

Daniel, D. R. (1961). Management of Information Crisis. Hardvard Business Review, 29(5), pp. 111-121.

Dinter, B. (2012). Success Factors for Information Logistics Strategy - An Empirical Investigation. Decision Support Systems, 54, pp. 1207-1218.

Edmondson, A. C., \& McManus, D. E. (2007). Methodological Fit in Management Field Research. Academy of Management Review, 32(4), pp. 1155-1179.

EHCR. (1996). Efficient Healthcare Consumer Response: Improving the Efficiency of the Healthcare Supply Chain. American society for Healthcare Material Management.

Eisenhardt, K. M. (1989). Building Theories from Case Study Research. Academy of Management Review, 14(4), pp. 532-550. 
Ellram, L. (1996). The Use of the Case Study Method in Logistics Research. Journal of Business Logistics, 17(2), pp. 93-138.

Eucomed. (2013). Eucomed - Medical technology. Retrieved März 20, 2013, from http://www.eucomed.be/medical-technology/value-benefits

Eucomed. (2015). What Medical Technology exactly is. Retrieved from http://www.eucomed.be/medical-technology

EY. (2013). Pulse of the Industry: Medical technology report 2013. Ernst \& Young Global Life Sciences Center.

FDA. (2014, December 08). Quality and Compliance (Medical Devices). Retrieved April 19, 2015, from U.S. Food and Drug Administration.

Focus. (2016, June 8). Die zwei großen Herausforderungen der Kassen. Retrieved September 11, 2018, from Online: https://www.focus.de/finanzen/experten/matusiewicz/krankenkassen-die-zwei-grossenherausforderungen-der-kassen_id_5604575.html

Garcia-Villarreal, E., Bhamra, R., \& Schönheit, M. (2014). The Critical Factors of the Medical Technology Supply Chains in the European Healthcare Sector: a Pilot Study. 21st EurOMA Conference: Operations Management in an Innovative Economy, (p. 10pp). Palermo, Italy.

Gibbert, M., Ruigrok, W., \& Wicki, B. (2008). What Passes as a Rigorous Case Study? Strategic Management Journal, 29(13), pp. 1465-1474.

GMDN-Agency. (2012). Global Medical Devices Nomenclature (GMDN) Agency. Retrieved April 30, 2013, from http://www.gmdnagency.com/

GMDN-Agency. (2015). Global Medical Devices Nomenclature (GMDN) Agency. Retrieved April 30, 2013, from http://www.gmdnagency.com/

Gunasekaran, A., \& Ngai, E. W. (2003). The Successful Management of a Small Logistics Company. International Journal of Physical Distribution and Logistics Management, 33(9), pp. 825-842.

Gunasekaran, A., \& Ngai, E. W. (2004). Virtual Supply Chain Management. Production Planning and Control, 15(6), pp. 584-595.

Handfield, R., \& Nichols, E. (2002). Supply Chain Redesign: Transforming Supply Chain into Integrated Value Systems. FT Press.

Hartford, J. (2014, December 19). Medical Device and Diagnostic Industry. Retrieved April 14, 2015, from http://www.mddionline.com/article/state-global-medtech-markets-12-19-2014

Hempel, V. (2017, June 17). Top 5 challenges for the German MedTech SME. Retrieved September 11, 2018, from Science Service - Dr. Hempel Digital Health Network: https://www.dr-hempel-network.com/medtec-medical-technology/digital-healthchallenges-german-medtech/

Hong, J. Y., Suh, E. H., \& Hou, L. Y. (2008). Identifying the Factors Influencing the Performance of Reverse Supply Chains (RSC). International Journal of Sustainable Engineering, 1(3), pp. 173-187. 
Hu, A. H., \& Hsu, C. W. (2010). Critical Factors for Implementing Green Supply Chain Management Practice: An Empirical Study of Electrical and Electronics Industries in Taiwan. Management Research Review, 33(6), pp. 586-608.

Institut für Mittelstandsforschung (IfM), Bonn. (2017). KMU-Definition des IfM Bonn. Retrieved February 28, 2017, from http://www.ifm-bonn.org/definitionen/kmu-definition-des-ifmbonn/

J \& M. (2010). Mittlere Reife für das Supply Chain Management - SCM in der Industrie etabliert. Nur wenige Champions. Mannheim: J \& M Research.

Kalorama Information. (2014). The Global Market for Medical Devices, 5th Edition. USA: Market Research Group, LLC.

Keck, K. L., Leigh, T. W., \& Lollar, J. G. (1995). Critical success factors in captive, multi-line insurance agency sales. Journal of Personal Selling \& Sales Management, 15(1), 17-33.

Kim, J., \& Rhee, J. (2012). An Empirical Study on the Impact of Critical Success Factors on the Balanced Scorecard Performance in Korean Green Supply Chain Management Enterprises. International Journal of Production Research, 50(9), pp. 2465-2483.

Koh, S. L., Gunasekaran, A., \& Goodman, T. (2011). Drivers, Barriers and Critical Success Factors for ERPII Implementation in Supply Chains: A Critical Analysis. The Journal of Strategic Information Systems, 20(4), pp. 385-402.

Korpela, J., \& Tuominen, M. (1996). Benchmarking Logistics Performance with an Application of the Analytic Hierarchy Process. IEEE Transactions on Engineering Management, 26(3), pp. 323-333.

Kraljic, P. (1983). Purchasing Must Become Supply Management. Hardvard Business Review, 61(5), pp. 109-117.

Kuei, C. H., \& Madu, C. N. (2008). Implementing Supply Chain Management. Total Quality Management, 19(11), pp. 1127-1141.

Lao, S. I., Choy, K. L., Ho, G. T., \& Chung, N. S. (2011). Determination of the Success Factors in Supply Chain Networks: A Hong Kong-based Manufacturer's Perspective. Measuring Business Excellence, 15(1), pp. 34-38.

Ledlow, G., Corry, A., \& Cwiek, M. (2007). Optimize your Healthcare Supply Chain: A Strategic Approach. Chicago, IL: Healthcare Administration Press.

Lettl, C. (2013). Die Rolle von Anwendern bei hochgradigen Innovationen: Eine explorative Fallstudienanalyse in der Medizintechnik. Springer.

Li, S., Ragu-Nathan, B., Ragu-Nathan, T. S., \& Rao, S. S. (2006). The impact of supply chain management practices on competitive advantage and organizational performance. The International Journal of Management Science, 34(2), pp. 107-124.

Lin, C., Kuei, C. H., \& Chai, K. W. (2013). Identifying Critical Enablers and Pathways to High Performance Supply Chain Management. International Journal of Operations and Production Management, 33(3), pp. 347-370.

Livesey, C. (2010). Sociological Research Skills - Sociology Central. Retrieved March 10, 2013, from www.sociology.org.uk/methsi.pdf 
Lucke, L., Mickelson, A., \& Anderson, D. (2009). Proving experience speeds medical device time to market. 31st Annual International Conference of the IEEE Engineering in Medicine and Biology Society (EMBS), (pp. 7057-7060).

Luthra, S., Mangla, S. K., Kumar, S., Garg, D., \& Haleem, A. (2017). Identify and prioritise the critical factors in implementing the reverse logistics practices: a case of Indian auto component manufacturer. International Journal of Business and Systems Research, 11(1-2), 42-61.

Mandal, S. (2017). The influence of dynamic capabilities on hospital-supplier collaboration and hospital supply chain performance. International Journal of Operations \& Production Management, 37(5).

Marucheck, A., Greis, N., Mena, C., \& Linning, C. (2011). Product Safety and Security in the Global Supply Chain: Issues, Challenges and Research Opportunities. Journal of Operations Management, 29(7-8), 707-720.

Mayr, A. (2013). Supply Chain Metrics That Matter: A Focus on Medical Device Manufacturers. Supply Chain Insights LLC.

McCurry, M., Moore, V., Kane, G., \& Ledlow, G. (2005). Sisters of Mercy Supply Chain.

Medina, L. A., Jankovic, M., Okudan Kremer, G. E., \& Yannou, B. (2013). An investigation of critical factors in medical device development through Bayesian networks. Expert Systems with Applications, 40(17), pp. 7034-7045.

Medina, L., Okudan Kremer, G., \& Wysk, R. (2012). An analysis of critical factors in medical device development to design for FDA. ASME 2012 International Design Engineering Technical Conferences, (pp. 1-10).

Medtech Europe. (2013). The European Medical Technology Industry in Figures. Retrieved April 19, 2015, from Eucomed: http://www.eucomed.org/uploads/Modules/Publications/the_emti_in_fig_broch_12_page s_v09_pbp.pdf

Medtech Europe. (2017). The European Medical Technology Industry - in Figures / 2018. Medtech Europe.

Mentzer, J., DeWitt, W., Keebler, J., Min, S., Nix, N., Smith, C., et al. (2001). Defining supply chain management. Journal of Business Logistics, 22(2), 1-25.

Miles, M., \& Huberman, A. (1994). Qualitative Data Analysis: An Expanded Sourcebook. Thousand Oaks, CA: Sage Publications, Inc.

Millson, M., \& Wilemon, D. (1998). Managing innovation in the medical device industry. International Conference on Engineering and Technology Management (IEMC), (pp. 213220).

Morton, S. C., Dainty, A. R., Burns, N. D., Brookes, N. J., \& Backhouse, C. J. (2006). Managing Relationships to Improve Performance: A Case Study in the Global Aerospace OIndustry. International Journal of Production Research, 44(16), pp. 3227-3241.

Mothilal, S., Gunasekaran, A., \& Nachiappan, S. P. (2012). Key Success Factors and Their Performance Implications in the Indian Third-Party Logistics (3PL) Industry. International Journal of Production Research, 50(9), pp. 2407-2422. 
Munro, M. C., \& Wheeler, B. R. (1980). Planning, Critical Success Factors, and Management's Information Requirements. MIS Quarterly, 4(4), pp. 27-38.

Narayanan, A. (2009). Healthcare Supply Chains - Is it Unique? Proceedings of the Annual Meeting of the Association of Collegiate Marketing Educators, (pp. 94-103). Oklahoma City.

Ngai, E. W., Cheng, T. C., \& Ho, S. S. (2004). Critical Success Factors in Web-based Supply Chain Management Systems: An Exploratory Study. Production Planning and Control, 15(6), pp. 622-630.

Nguyen, P. (2017, December 1). Theoretical of Critical Success Factors in Logistics and Supply Chain Operations Management: An Empirical Study. Operations Research Management, $6(9)$.

Ogden, J. A. (2006). Supply Base Reduction: An Empirical Study of Critical Success Factors. Journal of Supply Chain Management, 42(14), pp. 29-39.

O'Keeffe, K. (2011, June 10). The Rise of Medtech - MDDI Medical Device and Diagnostic Industry Products. Retrieved from http://www.mddionline.com/article/rise-medtech

Payne, A., \& Frow, P. (2005). A Strategic Framework for Customer Relationship Management. Journal of Marketing, 69, 167-176.

Pettit, S., \& Beresford, A. (2009). Critical Success Factors in the Context of Humanitarian Aid Supply Chains. International Journal of Physical Distribution and Logistics Management, 39(6), pp. 450-468.

Power, D. J., Sohal, A. S., \& Rahman, S. U. (2001). Critical Success Factors in Agile Supply Chain Management: An Empirical Study. International Journal of Physical Distribution and Logistics Management, 31(4), pp. 247-265.

Prajogo, D., \& Oke, A. (2016). Human capital, service innovation advantage, and business performance: the moderating roles of dynamic and competitive environments. International Journal of Operations \& Production Management, 36(9), 974-994.

Reck, R., Landeros, R., \& Lyth, D. (1992). Integrated Supply Management: The Basis for Professional Development. International Journal of Purchasing and Materials Management, 28(3), 12-18.

Rivard-Royer, H., Landry, S., \& Beaulieu, M. (2002). Hybrid stockless: a case study: Lessons for health-care supply chain integration. International Journal of Operations \& Production Management, 22(4).

Robson, C. (2011). Real World Research: a Resource for Users of Social Research Methods in Applied Settings. Chichester: Wiley.

Rochford, L., \& Rudelius, W. (1997). New product development process: stages and successes in the medical products industry. Industrial Marketing Management, 26, pp. 67-84.

Rockart, J. F. (1979). Chief Executives Define Their Own Data Needs. Retrieved from Hardvard Business Review: https://hbr.org/1979/03/chief-executives-define-their-own-dataneeds/ar/1 
Sanvido, V., Grobler, F., Parfitt, K., Guvenis, M., \& Coyle, M. (1992). Critical success factors for construction projects. Journal of construction engineering and management, 118(1), pp. 94-111.

Schönheit, M. (1997). Wirtschaftliche Prozessgestaltung - Entwicklung, Fertigung, Auftragsabwicklung. Heidelberg: Springer.

Seuring, S. (2013). A review of modeling approaches for sustainable supply chain management. Decision support systems, 54(4), 1513-1520.

Sheldon, D. H. (2006). World Class Sales \& Operations Planning: A Guide to Successful Implementation and Robust Execution. Ft. Lauderdale, Florida: J. Ross Pub.

Smith, B. K., Nachtmann, H., \& Pohl, E. A. (2012). Improving Healthcare Supply Chain Processes via Data Standardization. Engineering Management Journal, 24(1), pp. 3-10.

Soin, S. S. (2004). Critical Success Factors in Supply Chain Management at High Technology Companies. DBA thesis, University of Southern Queensland.

Sorenson, C., \& Kanavos, P. (2011). Medical Technology Procurement in in Europe: A CrossCountry Comparison of Current Practice and Policy. Health Policy, 100, 43-50.

Strozzi, F., \& Colicchia, C. (2015). Information processing and management using citation network and keyword analysis to perform a systematic literature review on Green Supply Chain Management. Journal of scientometric research, 4(3), 195.

Supply Chain Association. (2015). Understanding How Group Purchasing Organizations Work Why Administrative Fee Payments Keep Hospital and Patient Costs Down. Retrieved April 20, 2015, from Supply Chain Association: http://c.ymcdn.com/sites/www.supplychainassociation.org/resource/resmgr/research/ad min_fees.pdf

Sürie, C., \& Reuter, B. (2015). Supply Chain Analysis. In H. Stadtler, \& C. Kilger, Supply Chain Management and Advanced Planning (3rd ed., pp. 29-54). Berlin - Heidelberg: Springer.

Swift, R. S. (2000). Accelerating Customer Relationships - Using CRM and Relationship Technologies. Upper Saddle River, NJ: Prentice Hall.

Talib, M. S., \& Hamid, A. B. (2014). Application of Critical Success Factors in Supply Chain Management. International Journal of Supply Chain Magement, 3(1), 21-33.

Tan, K. (2001). A Framework of Supply Chain Management Literature. European Journal of Purchasing and Supply Management, 7, 39-48.

Tate, K. (1995). The Elements of Successful Logistics Partnership. International Journal of Physical Distribution and Logistics Management, 26(3), 4-22.

Thakkar, J., Kanda, A., \& Deshmukh, S. G. (2013). Supply Chain Issues in SMEs: Select Insights from Cases of Indian Origin. Production Planning and Control, 24(1), 47-41.

Thomas, D. J., \& Griffin, P. M. (1996). Coordinated Supply Chain Management. European Journal of Operational Research, 94(1), 1-15.

Trkman, P. (2010). The critical success factors of business process management. International journal of information management, 30(2), pp. 125-134. 
Tummala, V. R., Phillips, C. L., \& Johnson, M. (2006). Assessing Supply Chain Management Success Factors: A Case Study. Supply Chain Management: An International Journal, 11(2), 179-192.

Vlachos, D., Georgiadis, P., \& lakovou, E. (2007). A System Dynamics Model for Dynamic Capacity Planning of Remanufacturing in Closed-Loop Supply Chains. Computers and Operations Research, 34, pp. 367-394.

Volery, T., \& Lord, D. (2000). Critical success factors in online education. International Journal of Educational Management, 14(5), pp. 216-223.

Wong, K. Y. (2005). Critical Success Factors for Implementing Knowledge Management in Small and Medium Enterprises. Industrial Management \& Data Systems, 105(3), pp. 261-279.

Wu, J. Z., \& Hsu, C. Y. (2009). Critical Success Factors for Improving Decision Quality on Collaborative Design in the IC Supply Chain. Journal of Quality, 16(2), 95-108.

Yin, R. K. (2009). Case Study Research: Design and Methods (Vol. 4). Thousand Oaks: Sage Publications.

Zhu, Q., \& Sarkis, J. (2004). Relationships Between Operational Practices and Performance Among Early Adopters of Green Supply Chain Management Practices in Chinese Manufacturing Enterprises. Journal of Operations Management, 22, 265-89.

Zutshi, A., \& Sohal, A. S. (2004). Adoption and Maintenance of Environmental Management Systems: Critical Success Factors. Management of Environmental Quality: An International Journal, 15(4), pp. 399-419. 


\section{Appendix 1 - Interview Questions}

\begin{tabular}{|c|c|}
\hline \multicolumn{2}{|c|}{ Interview questions } \\
\hline 1 & $\begin{array}{l}\text { Can you please provide some general information about your company, including products, } \\
\text { number of employees, and annual revenue? }\end{array}$ \\
\hline 2 & How long have you been part of your organisation and in which position(s)? \\
\hline 3 & $\begin{array}{l}\text { How would you describe the major material and information flows managed by your } \\
\text { organisation's supply chain? }\end{array}$ \\
\hline 4 & $\begin{array}{l}\text { How would you describe your organisation's strategic approach to supply chain management? } \\
\text { How do customers, suppliers, and other stakeholders influence this approach? }\end{array}$ \\
\hline 5 & Which external and internal factors affect your organisation's supply chain operations? \\
\hline 6 & What are the major enablers and barriers to supply chain management in your organisation? \\
\hline 7 & How would you describe your organisation's position in comparison to your competitors? \\
\hline 8 & $\begin{array}{l}\text { Please provide examples of projects and processes set up in order to improve your } \\
\text { organisation's supply chain. How do these contribute to achieving your organisation's goals? }\end{array}$ \\
\hline 9 & $\begin{array}{l}\text { From your point of view, which activities should your organisation drive in the future to } \\
\text { improve its supply chain operations? }\end{array}$ \\
\hline 10 & $\begin{array}{l}\text { Are there any other issues that you are aware of that might help us in our research into the } \\
\text { critical success factors of supply chain management in your sector? }\end{array}$ \\
\hline
\end{tabular}

